\title{
Roma Do̊neminde Anadolu Kökenli Korinth Başlıklarının Yayılım Alanı: Sanat ve Sanatçının Devinimi
}

\section{Fatih Hakan Kaya*}

\section{Özet}

MÖ I. yüzyıldan itibaren imparatorluk kimliği kazanmaya başlayan Roma, hemen hemen tüm Akdeniz coğrafyasının mutlak hâkimi haline gelmişti. Gerek Roma'da gerek merkezden yönetilen eyaletlerde İmparatorluk, ihtişamını düzenli şehirler ve bu şehirlerde girişilen imar faaliyetleri ile göstermekteydi. Akdeniz'de yaşanmaya başlanan Roma Barışı ile gelişen ticaret sonucunda kalabalıklaşan kentlerde kamusal alanların yeniden düzenlenmesi, hatta imar edilmesi ihtiyacı doğmuştur. Bu yaşanan hızlı gelişim sonucunda Helenistik dönemden beri taş bezemeciliğinde öne çıkan kentler, yeni imar edilen Roma kentlerinde mimari bezeme biçemleri ile yeni akımlar yaratmışlardır. Ephesos, Pergamon ve Aphrodisias gerek hammaddeye olan yakınlığı gerek plastik işçiliğindeki gelenekleri nedeniyle tüm Anadolu, hatta Akdeniz coğrafyasında hâkim akımlar haline gelmiştir. MS II. yüzyılın ikinci yarısından itibaren mimari plastik ve bezeme biçemini etkisi altına almaya başlayan Aphrodisias Okulu'nun yaratılarını, Roma, Yunanistan, Suriye-Filistin ve Kuzey Afrika'nın yeniden imar edilen kentlerinde görmek mümkündür. Aphrodisias Bezeme Okulu'nun özgün biçemini yansıtan eserlerin yanı sıra Anadolu dışında üretilen eserlerde yerel biçemlere, hatta unsurlara yer verdiği örneklere de rastlamak mümkündür. Yazılı kaynaklara göre Roma İmparatorluğu tekelinde olan taş ocaklarından mimari elemanlar yarı işlenmiş olarak sevk edilmekteydi. Olasılıkla sevk edilen bu başlıklara taş ustaları da eşlik etmekteydi. Farklı lisanların konuşulduğu ve birden çok ırkın bir arada yaşadığı Roma kentlerinde, bu taş "ticareti" sanatsal etkileşim ile birlikte kültürel etkileşimi de beraberinde getirmekteydi.

Anahtar sözcükler: Roma, Anadolu, mimari, sanat, devinim

\section{Abstract \\ Spread of Corinthian Capitals of Asia Minor Origin During the Roman Period: Art and Artist in Motion}

Acquiring an imperial identity from the first century BCE onwards, Rome had become the absolute ruler of almost all of the Mediterranean. The Empire displayed its grandeur through building and construction activities as well as well-ordered cities both in Rome and in its provinces. Rising population of cities, due to increased trade activities following the Roman Peace (Pax Romana), necessitated reorganization and even reconstruction of public spaces. As a result of this rapid development, the cities once prominent in stone ornamentation during the Hellenistic period created new trends with their architectural ornamentation styles in the newly built Roman cities. Ephesos, Pergamon and Aphrodisias became dominant schools in Asia Minor and even throughout the Mediterranean due to their proximity to raw materials and their long tradition of stonework. It is possible to see the works of Aphrodisias School, which started to influence the architectural ornamentation style from the second half of the 2nd century onwards, in the newly built cities in Rome, Greece, Syria-Palestine and North Africa. In addition to the works that reflect the original style of Aphrodisias Ornamentation School, it is possible to see examples that include local styles and even elements in the works produced outside of Asia Minor. According to the written sources, the architectural elements of the stone quarries monopolized by the Roman Empire were shipped in semi-finished form. They were probably accompanied by stonemasons. In the multilingual and multiracial Roman cities this stone "trade" brought cultural interaction together with artistic interaction.

Keywords: Roman, Asia Minor, architecture, art, motion

* Dokuz Eylül Üniversitesi, Arkeoloji Bölümü 


\section{Giriş}

MÖ I. yüzyıldan itibaren imparatorluk kimliği kazanmaya başlayan Roma, MS I. yüzyıldan itibaren hemen hemen tüm Akdeniz coğrafyasının mutlak hâkimi haline gelmişti. Roma'da ve merkezden yönetilen eyaletlerde İmparatorluk, ihtişamını düzenli şehirler ve bu şehirlerde girişilen imar faaliyetleri ile göstermekteydi.

Uzun yıllar Helen krallıklarınca yönetilen ve yerleşik bir kültür ile sanata sahip olan Anadolu, son Helenistik Dönem krallığı olan Pergamon'un, Kral III. Attalos'un MÖ 133 yılında ölümünün ardından miras yolu ile Roma Cumhuriyeti'ne devredilmesi sonucunda tamamıyla Roma egemenliği altına girmiştir. Augustus döneminde Akdeniz'de yaşanmaya başlanan "Roma Barışı" ile kısmen de olsa askeri harcamalar azalmış, buradan aktarılan kaynaklar ve gelişen ticaret sonucunda kalabalıklaşan kentlerde kamusal alanların yeniden düzenlenmesi, hatta imar edilmesi ihtiyacı doğmuştu. ${ }^{1}$ Uzun yıllar boyunca yerleşik kültürleri olan yönetim ve ticaret merkezlerinde yaşanan refah düzeyindeki bu artış, kentlerin kimliklerine de yansımıştı. Bu yaşanan hızlı gelişim sonucunda Helenistik dönemden beri taş bezemeciliğinde öne çıkan kentler, yeni imar edilen Roma kentlerinde mimari bezeme biçemleri ile yeni akımlar yaratmışlardır. Ephesos, Pergamon ve Aphrodisias hammaddeye olan yakınlığı ve plastik işçiliğindeki gelenekleri nedeniyle tüm Anadolu, hatta Akdeniz coğrafyasında hâkim akımlar haline gelmişti. MS II. yüzyılın ikinci yarısından itibaren mimari plastik ve bezeme biçemini etkisi altına almaya başlayan Aphrodisias Okulu'nun yaratılarını, Roma, Yunanistan, Suriye-Filistin ve Kuzey Afrika'nın yeniden imar edilen kentlerinde görmek mümkündür. Aphrodisias Bezeme Okulu'nun özgün biçemini yansıtan eserlerin yanı sıra Anadolu dışında üretilen eserlerde yerel biçemlere, hatta yeni mimari unsurlara yer verilen örneklere de rastlamak mümkündür.

Roma İmparatorluğu'nun o dönemdeki büyüklük ve gücünü tam olarak kavrayabilmek için, bugün aynı topraklar üzerinde yaklaşık otuz devletin var olduğunu belirtmek yeterli olacaktır. Kuzey Afrika'dan İngiltere'ye Atlantik kıyılarından Kızıldeniz'e kadar uzanan bir alana yayılan bu çok uluslu imparatorluk (Şek. 1) sınırları içerisinde yaklaşık 60 milyon insanın yaşadığı öngörülmektedir ki bu o zaman için bilinen dünya nüfusunun beşte birine tekabül etmektedir. ${ }^{2}$

İmparatorluk egemenliğine giren ve eyaletler olarak organize edilen eski Helenistik krallıklar başlangıçta "taşra" olarak tanımlanıp küçümsendilerse de zamanla sanat ve kültür değerleriyle yaşam biçimleri, karşılıklı etkileşimin bir sonucu olarak Roma'da ve eyaletlerde yeni bir yaşam biçimi ve sanat anlayışının doğmasına neden olmuş ve Roma bu sayede mermer ile tanışmıştır. ${ }^{3}$ Ancak Etrüsklere değin giden köklü bir mimari geleneğe sahip olan Roma'nın alışılagelmiş malzemeleri terk ederek mermer kullanımını benimsemesi zaman almıştır. Bu durumu en iyi Augustus'un söylediği rivayet edilen "Tuğladan bir şehir buldum, mermerden bir şehir bırakıyorum"s sözü açıklamaktadır. Öyle ki bu sözün

1 Jona Lendering, Roma: Mermer Şehir, çev. Burak Şengir (İstanbul: Kitap Yayınevi, 2011), 78.

2 Tulga Albustanlığlu, Roma Imparatorluk Döneminde Mermer Ocakları Organizasyonu (Ankara: Bilgin Kültür Sanat, 2011), 1.

3 Albustanlığlu, Roma Imparatorluk, 2.

4 Gaius Suetonius Tranquillus, Divus Augustus, 28.3. 


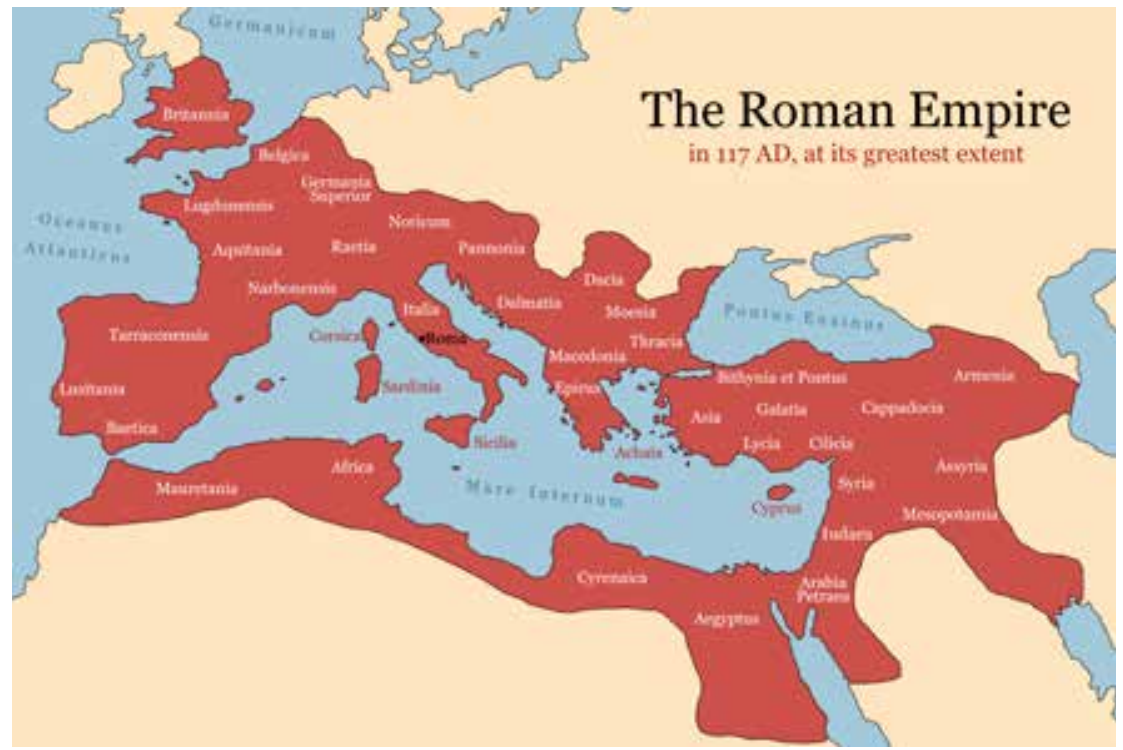

Şekil 1. MS II. yüzyıl başlarında Roma İmparatorluğu'nun hâkimiyet alanı.

gerçekliği üzerinden bir yorum yapılması durumunda Augustus dönemi öncesinde ve sırasında Roma kentini bakımsız, sönük ve donanımsız bir kent olarak tanımlamak mümkündür. ${ }^{5}$ Augustus'un bu denli büyük bir imar faaliyetine girişip girişmediği son zamanlarda tartışılsa da, bir idealin olduğu açıktır.

Roma'da yaşanmaya başlanan bu "Mermer Çağı"nı yalnızca İmparatorun zevklerine ve ideallerine uygun kentler oluşturmaya çalışması ile açıklamak hatalı olacaktır. Kaliteli mermer bulabilmek, ocakları işletmek, mermerin sevkiyatı ve işlenmesi gibi başlıca sorunların da aşılması gerekmekteydi. Bu yönü ile bakıldığında mermer kullanımının ilk olarak Augustus döneminde değil, daha önce Iulius Caesar tarafından Luna (Carrara) ocaklarının açılması ile başladığını söylememiz gerekir (Şek. 2). ${ }^{6}$ Luna mermer ocakları açılıncaya değin Roma'da mermer denilince sadece Pentelikon mermer ocaklarından gelen mermerlerin kullanıldığını görmekteyiz. Ancak Luna mermerinin yüksek kalitesi, bolluğu ve ulaşım imkânlarının kolaylığı nedeniyle maliyetler düşmüş, bu sebeple de zamanla mermer tercih edilen yapı malzemesi haline gelmiştir. ${ }^{7}$ Roma'da mermer kullanımının Carrara mermer ocaklarının işletilmeye başlaması ile bir anda zirveye çıktığ1 düşüncesi yanlış olacaktır. Bu noktada Romalı mimarların ve şehir plancılarının Yunanlardan öykündüklerini söylemek mümkündür. Kaldı ki Iulius Caesar döneminde gerçekleştirilen Iulian Forumu Venus Genetrix Tapınağ (Şek. 3), Curia Iulia ve Saepta gibi birçok projede çalışacak yerli kalifiye mermer ustaları bulunamadığı için, Yunan ve Anadolu kökenli taş ustalarının çalıştırıldıkları bilinmektedir. Augustus döneminde de bu yabancı kökenli taş ustaları

5 Axel Boëthius, Roger Ling, Tom Rasmussen, Etruscan and Early Roman Architecture (New Haven: Yale University Press, 1978), 214; Paul Zanker, The Power of Images in the Age of Augustus (Ann Arbor: University of Michigan Press, 1988), 65; Albustanlığlu, Roma İmparatorluk, 3.

6 Albustanlığlu, Roma Imparatorluk, 3.

7 Albustanlığlu, Roma Imparatorluk, 3. 


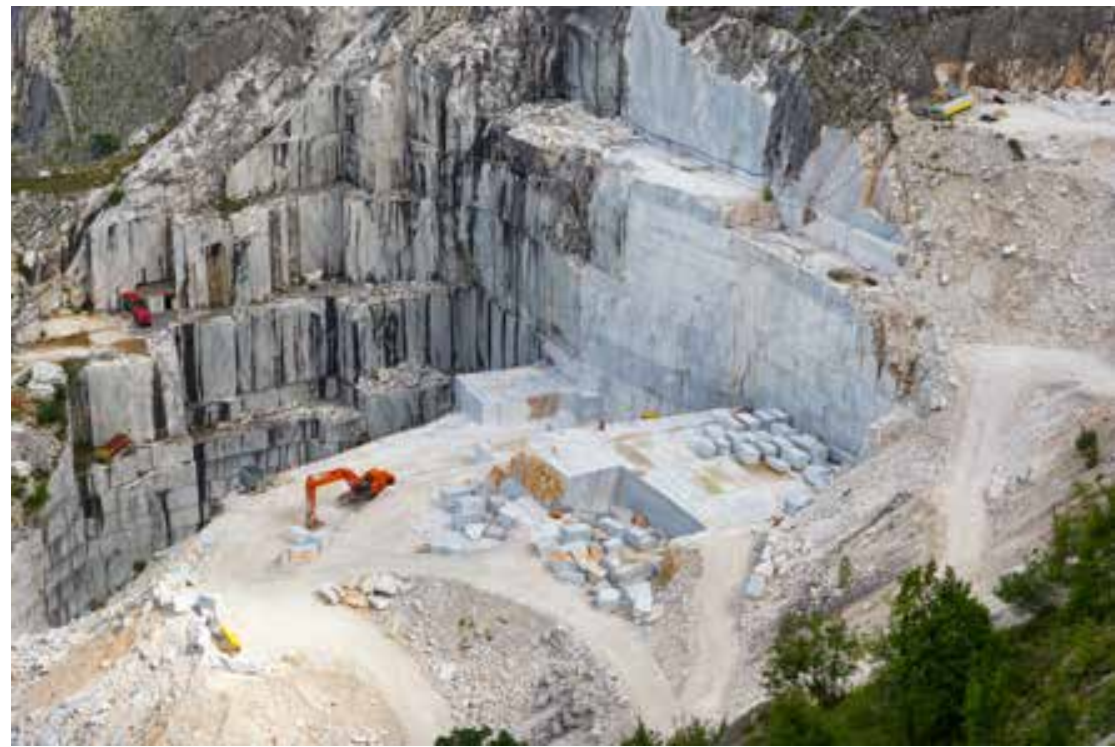

Şekil 2. Carrara Mermer ocaklarının günümüzdeki hali.

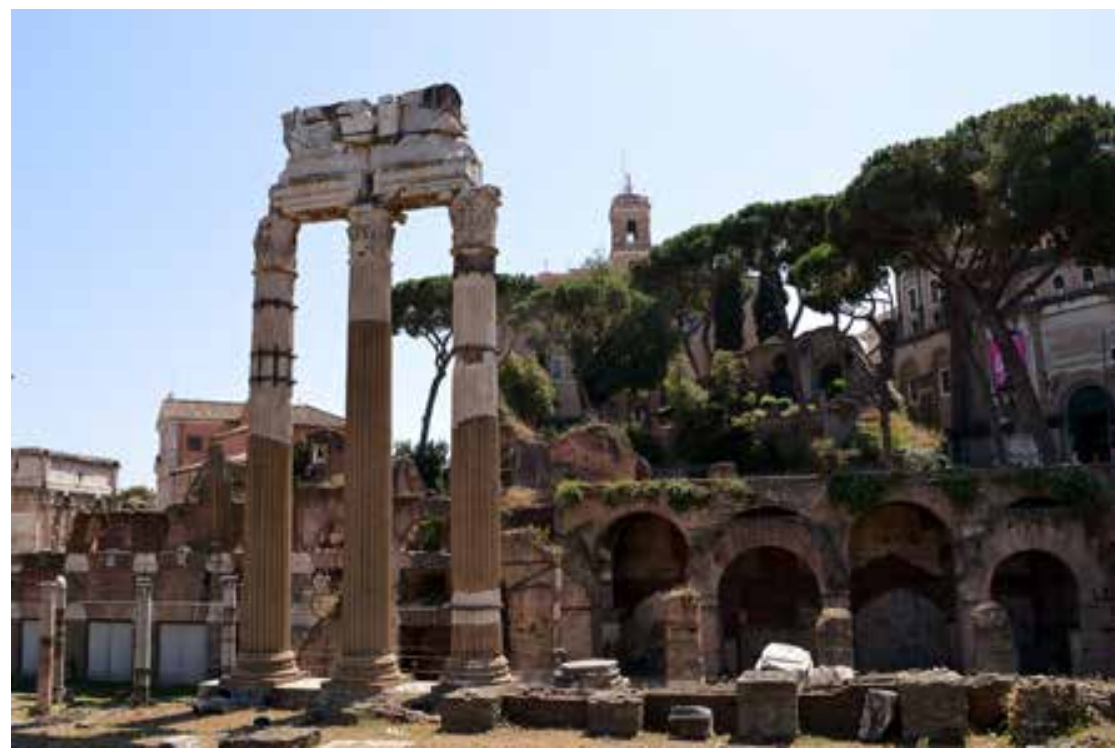

Şekil 3. Iulian Forumu Venus Genetrix Tapınağı.

kentin kimliğini değiştirmek isteyen imparatorun arzusuna paralel olarak girişilen imar projelerinde Carrara mermerinden eserler vermişlerdir.8 Augustus Forumu'nun yer yer Atina ve Pergamon özellikleri sergilemesini de bu neden ile doğal karşılamak gerekir. ${ }^{9}$

8 Albustanlığlu, Roma Imparatorluk, 3.

9 Albustanlığlu, Roma Imparatorluk, 5. 
Carrara ocaklarından elde edilen mermer, Roma kentinde Augustus ile başlayan ve ardılları tarafından da bir imar yarışına dönüştürülen bu yeni kentleşme modeli için gerekli olan yüksek miktardaki mermer ihtiyacına cevap vermekte yetersiz kalmıştır. Bu nedenle imparatorluğun dört bir yanındaki mermer ocaklarının yeniden organize edilmesi gerekliliği ortaya çıkmıştır. Başta Atina'daki Pentelikon ocakları ve Anadolu'daki Dokimeion ocakları olmak üzere, Helenistik dönemden beri aktif olan ocaklar da Roma kentine mermer ihracatına hız vermiştir. ${ }^{10}$ İmparatorluğun merkezde ve eyaletlerde girişmiş olduğu bu imar faaliyetlerinin sonucunda yeniden organize edilen mermer ocakları zamanla büyük oranda imparatorluk mülkiyetine geçirilmiş, modern işletme teknolojileri sayesinde de üretim önemli ölçüde artmıştır. ${ }^{11}$

Roma'da mermer ocaklarının organizasyonuna bakıldığında mermer üretiminin ve kullanımının imparatorluk iradesinde olduğu ve yine imparatorun sağladığı imtiyazla taşeronluk yapan mermer ocaklarının da bulunduğu anlaşılmaktadır. ${ }^{12}$ Gerek imparatorluk idaresinde olsun gerek özel ocaklar olsun kamu binalarının yanı sıra, her ne kadar pahalı bir ticaret metası olsa da, özel mülkiyet binalarına da mermer sağlıyorlardı.

Helen krallıkları zamanından beri mermer işçiliğinde köklü bir geleneğe sahip olan Anadolu mermer ocakları ve ustaları Roma İmparatorluk döneminde büyük oranda rağbet görmüştür. Büyük bir kısmı bugün dahi kullanılan bu mermer ocaklarına bakılacak olduğunda, başta Marmara Adası (Prokonnesos), Afyon/İscehisar (Dokimeion), Aydın/Karacasu (Aphrodisias) gibi bilinen merkezlerin yanı sıra, İzmir/Sığacık (Africano), Muğla/Kıyıkışlacık (Iasos) gibi ocaklar da antik dönem imar faaliyetlerine hammadde sağlayan önemli merkezlerdir. Özellikle ihracat söz konusu olduğunda Prokonnesos, Dokimeion ${ }^{13}$ ve Aphrodisias ön plana çıkmaktadır. ${ }^{14}$

Mermer üretiminin yanı sıra, mermer işçiliği denildiğinde akla gelen en önemli merkez Aphrodisias'tır. Kent sınırları ve işletme sorumluluk alanında olan ocaklardan oldukça kaliteli mermerler çıkarılmaktadır. Önemli ihraç malzemesi olan ve kaliteli mermere sahip Aphrodisias kentinin imarında yerel mermer yerine ithal mermerin kullanılmış olması oldukça ilgi çekicidir. Kent genelinde yapılan araştırmalarda Africano (İzmir/Sığacık), Carystian (Yunanistan/Euboea), Iasos (Muğla/Kıyıkışlacık), Chios Rosso Antico (Yunanistan/ Sakız Adası) ve Laconia'dan (Yunanistan) mor ve yeşil porfir ile Dokimeion'dan (Afyon/İscehisar) Pavonazetto gibi ithal taşlar MS II. yüzyılda yapılmış binalarda görülmüştür. ${ }^{15}$

10 Albustanlığlu, Roma Imparatorluk, 6.

11 John Bryan Ward-Perkins, "Tripolitania and the Marble Trade", The Journal of Roman Studies 41, no 1 ve 2 (1951): 25.

12 Patrizio Pensabene, "Marmi d'Importazione, Pietre Locali e Committenza Nella Decorazione Architettonica di età Severiana in Alcuni Centri delle Province Syria et Palestina e Arabia", Archeologia Classica 49 (1997): 280; Lendering, Roma: Mermer Şehir, 81.

13 Dokimeion mermerinin daha çok döşeme ve kaplama malzemesi olarak kullanıldığına ilişkin yanlış kanının aksine büyük çaplı imar faaliyetlerinde sütun ve çeşitli üst yapı elemanlarında da kullanıldığını görebiliriz. Ephesos'daki Vedius ve Liman Hamamları, Celsus Kütüphanesi, Sardes'deki Gymnasion ve Side Sütunlu Caddesi Dokimeion mermerinin kullanıldığı yapılar arasında sayılabilir. Bkz. Albustanlığlu, Roma İmparatorluk, 18-19.

14 Albustanlığlu, Roma Imparatorluk, 21.

15 Albustanlığlu, Roma İmparatorluk, 21. 


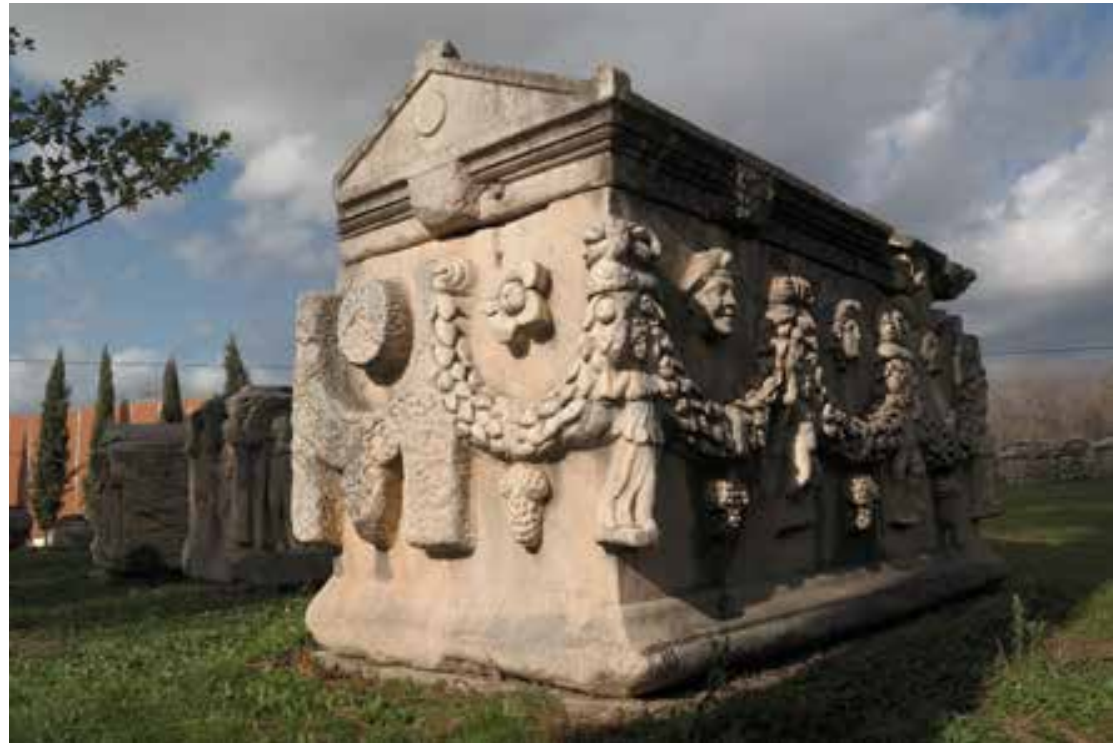

Şekil 4. Yarı işlenmiş mermer lahit. Aphrodisias Müzesi.

Roma İmparatorluk döneminde mermer üretimi ve işçiliği söz konusu oldugunda sadece imar faaliyetlerinden ve mermerin mimaride kullanılmasından bahsetmek hatalı olacaktır. Romalı yöneticilerin, soyluların, tüccarların ve her nevi kalburüstü tabakanın günlük hayatında zenginlik göstergesi olan mermer, aynı zamanda Romalı yurttaşların ölümden sonra, diğer hayatta kendilerini evlerinde hissedebilecekleri mezarlarının da temel malzemesini oluşturmaktadır. Eski çağlardan beri kabul gören ölümden sonraki yaşam inancı, Helenlerde ve Romalılarda, görkemli anıtların yapılamasına neden olmuştur. MS II. yüzyılda, Roma İmparatorluğu'nun hemen hemen bütün merkezlerinde gördüğümüz lahitler ölümden sonraki hayata ve iktisadi hayata ilişkin verdiği bilgiler açısından önemlidir. İşlenmiş ya da yarı işlenmiş olarak ocaklardan çıkan lahitlerin (Şek. 4) ${ }^{16}$ işçiliği, zarafeti, malzeme kalitesi, mermer cinsi ve işçilik unsurları aynı zamanda kentin ticari ilişkilerine de 1şık tutmaktadır. Örneğin Dokimeion lahitleri mesafelere bakılmaksızın Akdeniz havzasında yer alan birçok kente pazarlanmış ve sahibine ölümden sonraki hayat için mesken olmuştur. ${ }^{17}$ Hiç şüphesiz ki Anadolu'nun merkezinde, karayolu dışında bir ulaşım ağı olmayan Dokimeion, Prokonnesos gibi açık deniz limanlarına sahip Marmara Adası ya da nispeten denize daha yakın olan Aphrodisias gibi ocaklara nazaran ihracat söz konusu olduğunda dezavantajlı bir konumdaydı. Ancak Roma İmparatorluğu'nun iyi organize olmuş mermer ocağı yönetimi bu konuda da bir çözüm üretmişti. Ulaşım maliyetlerinin düşüklüğü nedeniyle Prokonnesos ocaklarının mermer borsasını yönetmesi çok olası iken, Marmara Adası'ndan gelen mermerlerin kalitesi yüksek, ulaşımı kolay ancak işçilikleri oldukça zayıf tutulmaktaydı. Buna karşın oldukça zor ulaşılan, kara yolu ile kentlere ya da limanlara

16 Pensabene, “Marmi d'Importazione”, 279.

17 Guntram Koch, Roma İmparatorluk Dönemi Lahitleri, çev. Z. Zühre İlkgelen (İstanbul: Arkeoloji ve Sanat Yayınları, 2001), 172. 


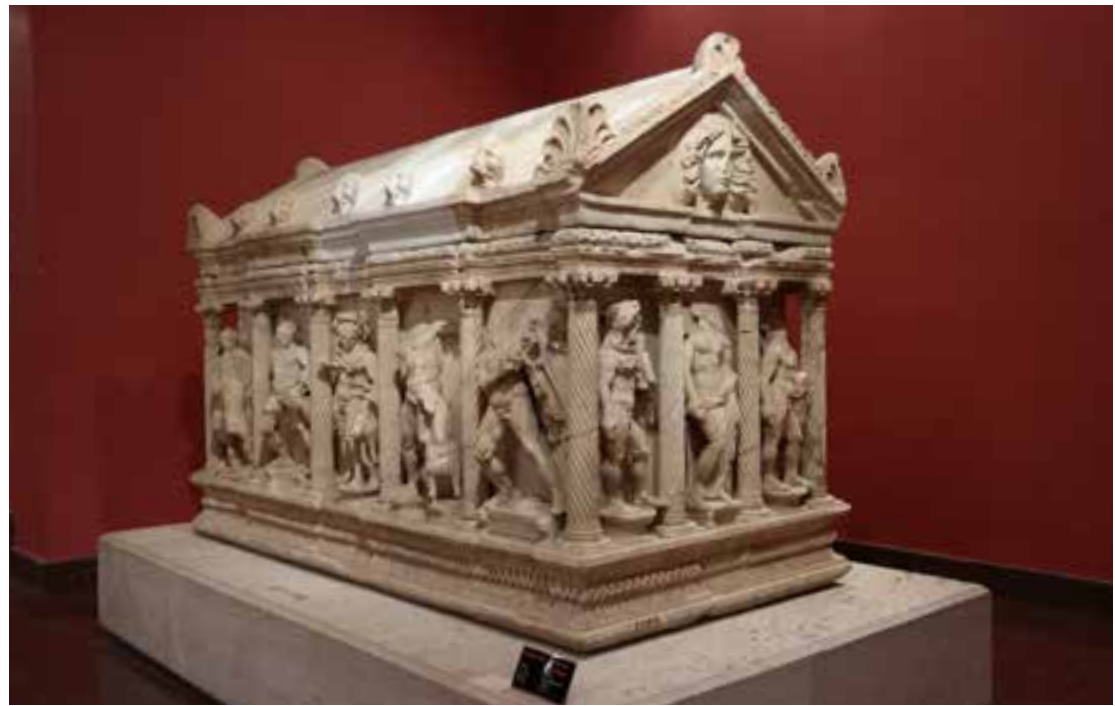

Şekil 5. Perge kazılarında bulunmuş olan Sütunlu Tip (Sidemara) Herakles lahti. MS II. yüzyıl.

ulaşmak zorunda kalan Dokimeion işliklerinden çıkan lahitler yoğun bir işçilik girdisiyle Prokonnesos ürünlerine kıyasla çok daha pahalı olan girland ve sütunlu tip (Sidemara) (Şek. 5) üretimiyle zengin bir alıcı kitlesine hitap etmeyi başarabilmiştir. ${ }^{18} \mathrm{Bu}$ yönü ile bakıldığında Dokimeion lahitleri olasılıkla kuzeyde Nikomedia (İzmit), batıda Smyrna (İzmir) ya da Ephesos (İzmir/Selçuk) ve güneyde ise Attaleia (Antalya) ya da Perge (Antalya/Aksu) kentlerinin limanlarından ihraç edilmiş olmalılar. Dağılımlarına bakılacak olduğunda ise; Suriye, Filistin ve Arabistan'da, Rodos, Girit, Atina, Dalmaçya, İtalya ve hatta Roma'da Dokimeion lahitlerinin örneklerine rastlanmaktadır. ${ }^{19}$

\section{Anadolu'daki Bezeme Okulları}

Antik Dönemde mermer ocaklarının organizasyonu ve işletilmesinin yanı sıra ocaklardan elde edilen hammaddenin nerede ve nasıl işlendiği de önemliydi. Roma İmparatorluk döneminde hızla sürdürülen imar projelerinde, Yunan işlikleri ile birlikte Anadolu'da Helenler döneminden beri heykel ve mimari plastik üzerine üretimde bulunan işliklerin de önemli ölçüde üretim yaptığı bilinmektedir. ${ }^{20}$ Bahsi geçen işlikler Roma mimarlığını önemli ölçüde etkilemiş ve sanat akımlarının tüm Akdeniz havzasına yayılmasında etkili olmuştur.

MÖ I. yüzyıldan beri geleneksel yapı formlarını geride bırakarak kendine yer bulan Korinth yapı formu (Şek. 6), zamanla Roma mimarisi ile özdeş hale gelmiştir. Özellikle Korinth başlıklarının, öncülleri Ion ve Dor başlıklarına nazaran zengin ve canlı bezemeleri Roma'nın yaratmak istediği ihtişama layık bir form olarak ortaya çıkmıştır. Bu halde biçem kritiği yapılmasında sağladığı

18 Albustanlığlu, Roma İmparatorluk, 36.

19 Koch, Roma İmparatorluk Dönemi, 172, 271, 280.

20 Wolf-Dieter Heilmeyer, Korinthische Normalkapitelle. Studien zur Geschichte der Römischen Architekturdekoration (Heidelberg: F. H. Kerle Verlag, 1970), 174. 


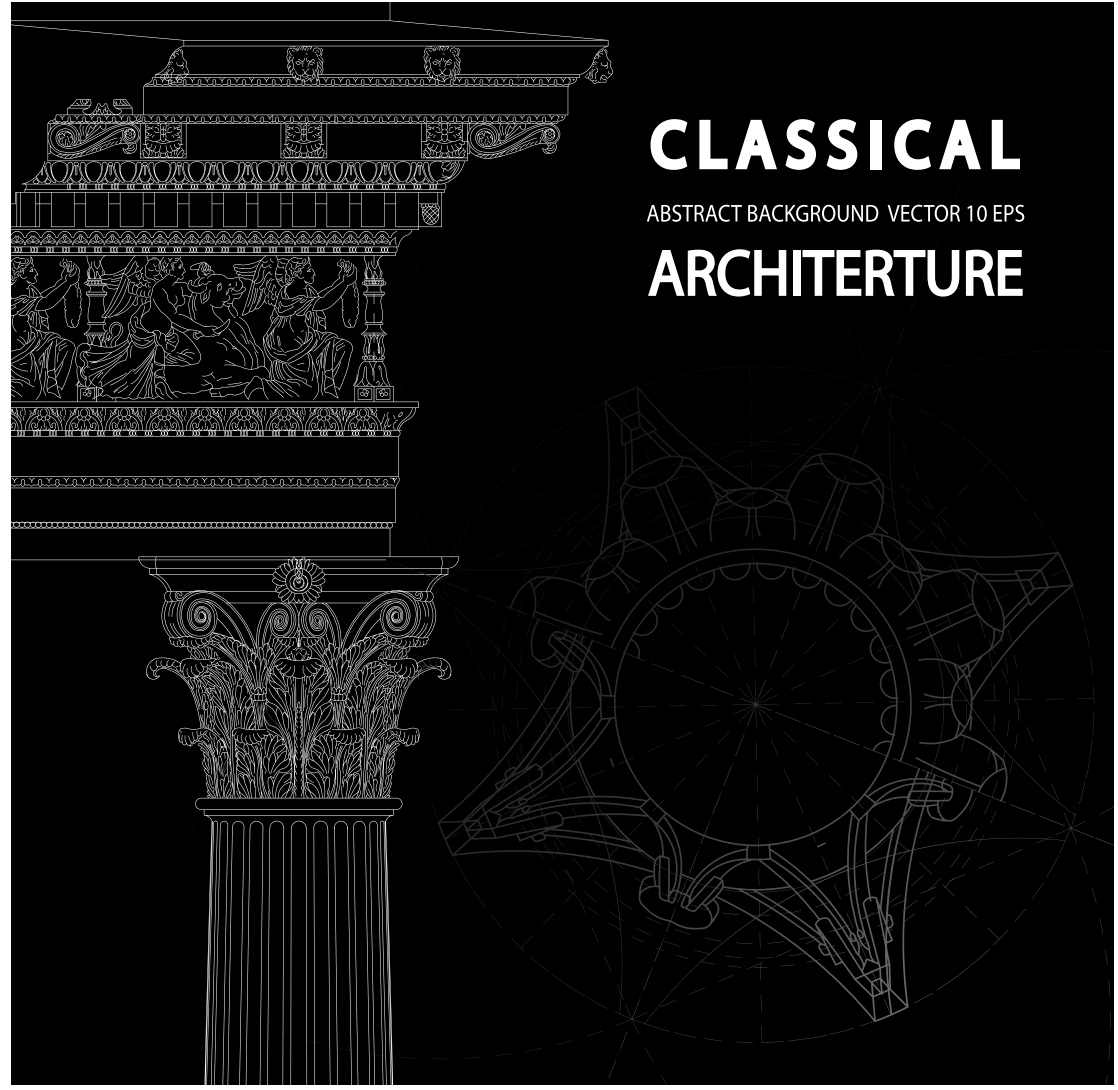

Şekil 6. Korinth Düzeni.

kolaylıklar nedeniyle irdelenmesi gereken mimari eleman Korinth başlıkları olmalıdır (Şek. 7). ${ }^{21}$

\section{Pergamon-Ephesos Bezeme Okulu}

Roma İmparatorluğu'nda, doğu eyaletlerinde yaşanan Romalılaşma sürecinde girişilen mimari faaliyetler sonucunda büyük kentler adeta şantiye alanına dönerek hızlı bir değişim geçirmekteydi. ${ }^{22}$ Asia Eyaleti'nin başkenti olan Ephesos bu dönüşümün de başkenti konumundaydı. MS I. yüzyılda Roma kentlerinin hızla imar edilmesinin sonucunda kalifiye eleman ihtiyacı doğmuştu. Helenistik dönemde heykeltıraşlık eserleri veren Pergamon bu ihtiyacı karş1layabilecek önemli merkezlerden biriydi ve Batı Anadolu'da yürütülen imar faaliyetleri sırasında, mimari bezeme söz konusu olduğunda, W. D. Heilmeyer tarafından Pergamon-Ephesos Bezeme Okulu olarak tanımlanan işlikler ön plana çıkmaktaydı. ${ }^{23}$

21 Heilmeyer, Korinthische Normalkapitelle, 173.

22 Pensabene, “Marmi d'Importazione", 275.

23 Heilmeyer, Korinthische Normalkapitelle, 93-97. 

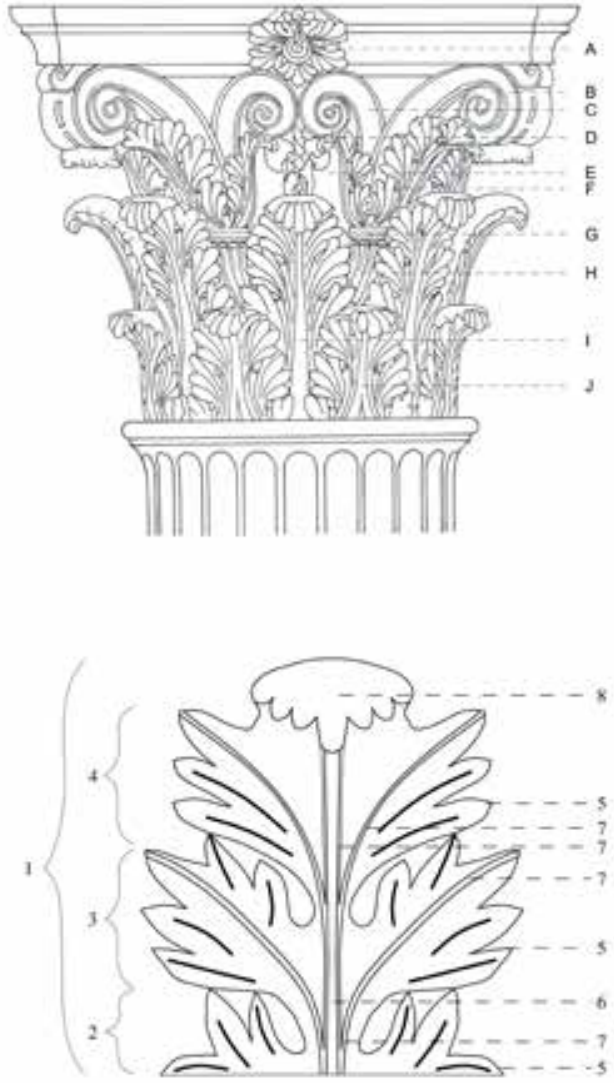

A. Abokus Ciged

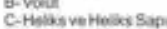
D-abevos Cigecissoi E. Kaxatios F. Kanis Canag G-Kadedogomaracogo 1. - Ost Nkanthus Yigrak 8ap. 1. Ninkanthua Yaorak Dema

Şekil 7. Korinth başlığı ve akanthus yaprağının bölümleri.

Pergamon-Ephesos Bezeme Okulu işliklerinden çıkan Korinth başlıklarında akanthus yapraklarının şekli tipolojiyi tanımlamak açısından belirleyici unsur olarak kabul edilmektedir. Genel hatlariyla bahsedecek olursak, akanthus yapraklarının ayrıntılı olarak işlendiği görülür. Yaprakların ana damarlarından yaprak uçlarına dek uzanan damarlar derin işlenmiştir. Yaprak dilimleri arasındaki geçişler yuvarlatılmıştır. ${ }^{24}$ Geniş alt sıra akanthus yaprakları ile bunların arasından yükselen üst sıra akanthus yaprakları başlık yüzeyini sıkıca sarmıştır. Akanthus yapraklarının zeminden dışa doğru taşmasıyla oluşan plastik etki ve sivri uçlu yaprak dilimlerinin birbirlerine bağlanmaları sonucu 1şık-gölge etkisi belirginleşmiştir. ${ }^{25}$

Pergamon-Ephesos Bezeme Okulu yaratılarını ve biçem özelliklerini anlayabilmek için Pergamon Traianus Tapınağı Korinth başlıklarına bakmak ge-

24 Cevat Başaran, "Kyzikos Korinth Başlıkları”, Türk Arkeoloji Dergisi 31 (1997): 5.

25 Benzer etkileri aynı dönem içerisinde imal edilmiş olan kompozit başlıklarda da görmek mümkündür. Akanthus yapraklarının işlenişi nedeniyle kompozit başlıklar ile Korinth başlıkları mimari bezeme unsuru olarak paralellik göstermektedir. Bkz. Cevat Başaran, Anadolu Kompozit Başlıkları (İstanbul: Arkeoloji ve Sanat Yayınları, 1999), 16. 


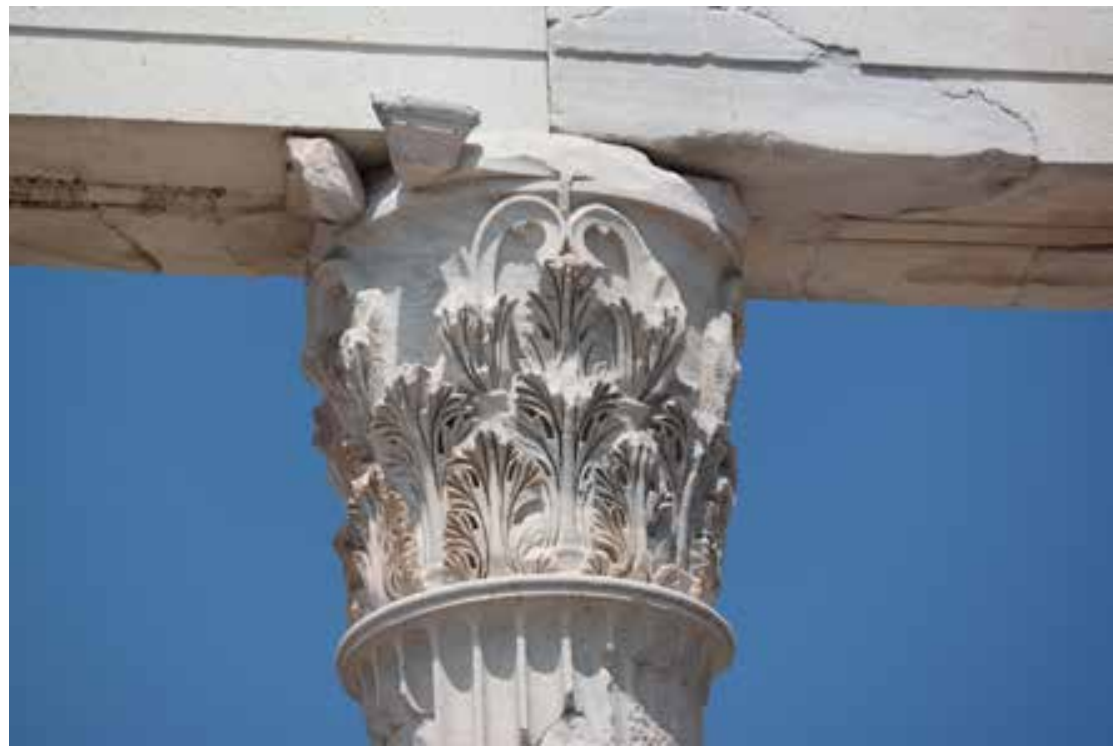

Şekil 8. Pergamon Traianus Tapınağı Korinth başlı̆̆ı.

reklidir (Şek. 8). Başlıklarda kalathos kuvvetli bir etki vermektedir. Kalathosun üstünü kaplayan iki sıra akanthus yaprakları kalathos yüzeyinden belirgin bir biçimde dışa taşmaktadır. Bu da yapraklardaki plastik etkiyi güçlendirmiştir. ${ }^{26}$ Üst sıra akanthus yaprakları alt sıra akanthus yapraklarının arasından yükselmektedir. Akanthus yapraklarının damarlarının daha ince ve derin oyulduğu görülebilmektedir. Yaprak dişlerinin üstlerinin içe doğru güzel bir biçimde oyulması 1şık-gölge oyununun etkisini artırmıştır. Kaulisler üst yaprakların arasında küçük birer prizma olarak yerlerini almışlardır. Başlı̆̆ın üst bölümünde, abakus levhasını taşıyan ve kırık olduğu görülen volütlerin altları derin oyulmuş, heliksler ise kalathos dudağının hemen altında içe doğru geniş bir kavisle kıvrılmıştır. Heliksler de volütler gibi güçlü bir etki bırakmaktadır. Bu derin oymalar başlıktaki ışık-gölge oyunu etkisini artırmaktadır. Kalın olarak işlenmiş olan abakus levhasının altındaki dudak alt kesiminde kalathosun içeriye doğru belli belirsiz bir kavis yapması ile güzel bir biçime sahip olmuştur. ${ }^{27}$

Traianus Tapınağı Korinth başlıklarının ince, zarif ve gösterişli bezemesinin varlığı ile biçem birliği W. D. Heilmeyer ${ }^{28}$ ve V. İdil tarafından Pergamon Bezeme Okulu olarak yorumlanmaktadır. ${ }^{29}$

Roma'da Augustus Forumu (Şek. 9) güney doğu eksedrasında yer alan bir adet Korinth başlığı ikonografisi, biçemi ve malzemesi bakımından diğer başlıklardan

26 Vedat İdil, "Anadolu'da Roma İmparatorluk Çağı Korinth Başlıkları”, Anadolu (Anadolu) 20 (1984): 17.

27 İdil, “Anadolu'da Roma”, 17.

28 Heilmeyer, Korinthische Normalkapitelle, 92.

29 İdil, “Anadolu'da Roma”, 17. 


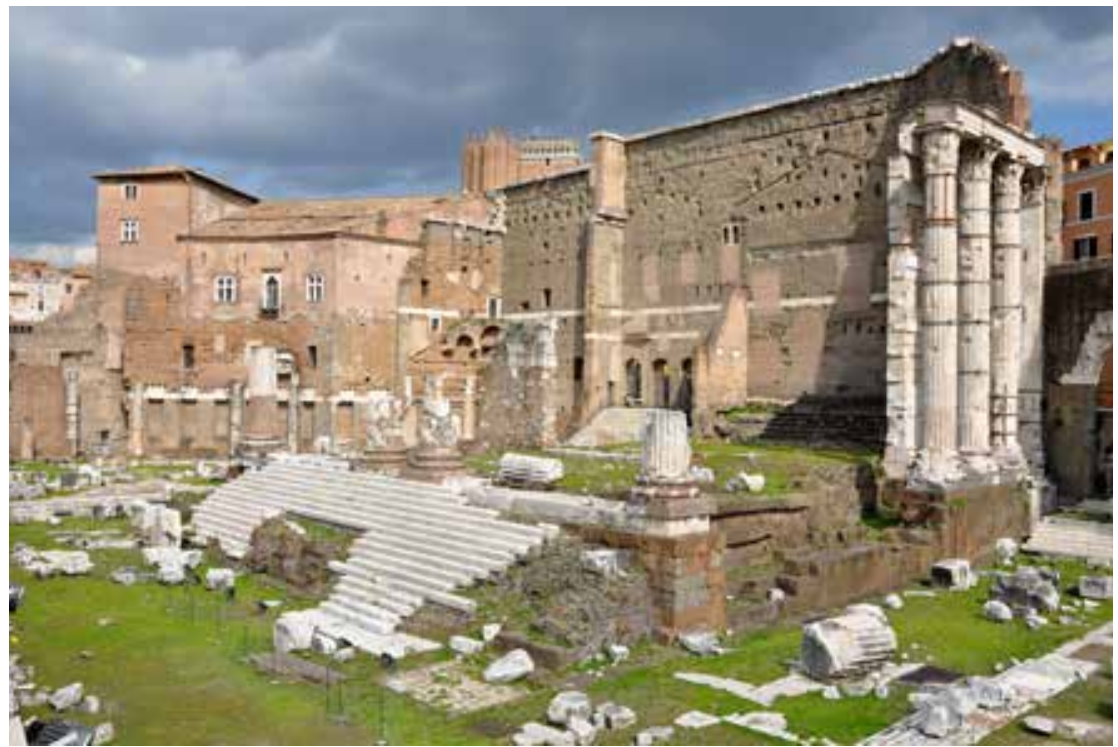

Şekil 9. Roma, Augustus Forumu.

farklıdır. ${ }^{30}$ Başlığın iri kristalli gri mermeri Prokonnesos'dan ithal edilmiştir. Bu başlık olasılıkla Hadrianus döneminde Augustus Forumu'nda yapılan yenileme çalışması sırasında güney doğu eksedraya eklenmiştir. Başlıkta görülen akanthus yapraklarının uçları Roma biçeminden uzak olup daha çok Doğu'ya özgü biçimde sivri ve derin olarak işlenmiştir. Geniş alt sıra akanthus yaprakları ile bunların arasından yükselen üst sıra yaprakları başlık yüzeyini kaplamıştır. Akanthus yapraklarının ana damarlarından yaprak uçlarına dek uzanan damarlar derin işlenmiş olup, zeminden dışa doğru taşmasıyla oluşan plastik etki ve sivri uçlu yaprak dilimlerinin birbirlerine bağlanmaları sonucu 1şık-gölge etkisi belirginleşmiştir. Bu başlıkta görülen yaprak biçemini Pergamon Traianus Tap1nağı başlıklarında görmek mümkündür. Pergamon Traianus Tapınağı'nın Hadrianus döneminde inşa edildiği göz önünde bulundurulursa ${ }^{31}$ Augustus Forumu'nda gördüğümüz örnek de biçem olarak Hadrianus dönemine tarihlenmelidir. ${ }^{32}$ Başlığın akanthus yapraklarının kalathos yüzeyinde geniş ve yüksek işlenmesi, sivriltilmiş yaprak dişleri ile bu dişlerin yaprak dilimlerini birbirine bağlarken oluşturdukları 1şık-gölge oyunları, derin oyulmuş kanallar ve bu kanalların güçlü damarların ucuna kadar uzanmaları, plastik özelliklerinin artırılmış olması gibi özellikleri nedeniyle yaprakların Anadolu biçeminde, genel olarak da Pergamon-Ephesos Bezeme biçeminde işlendiklerini söylemek mümkündür.

30 Donald Emrys Strong, "Late Hadrianic Architectural Ornament in Rome", Papers of the British School at Rome 21 (1953): 139, Dnt. 89; Heilmeyer, Korinthische Normalkapitelle, 32, Dnt 121; Klaus S. Freyberger, Stadtrömische Kapitelle aus der Zeit von Domitian bis Alexander Severus: zur Arbeitsweise und Organisation Stadtrömischer Werkstätten der Kaiserzeit (Mainz am Rhein: P. Von Zabern, 1990), 61, Levha (Lev.) 19a.

31 Heilmeyer, Korinthische Normalkapitelle, $90 \mathrm{vd}$.

32 Ward-Perkins, "Nicomedia and the Marble Trade", Papers of the British School at Rome 48 (1980): 62; Freyberger, Stadtrömische Kapitelle, 62. 


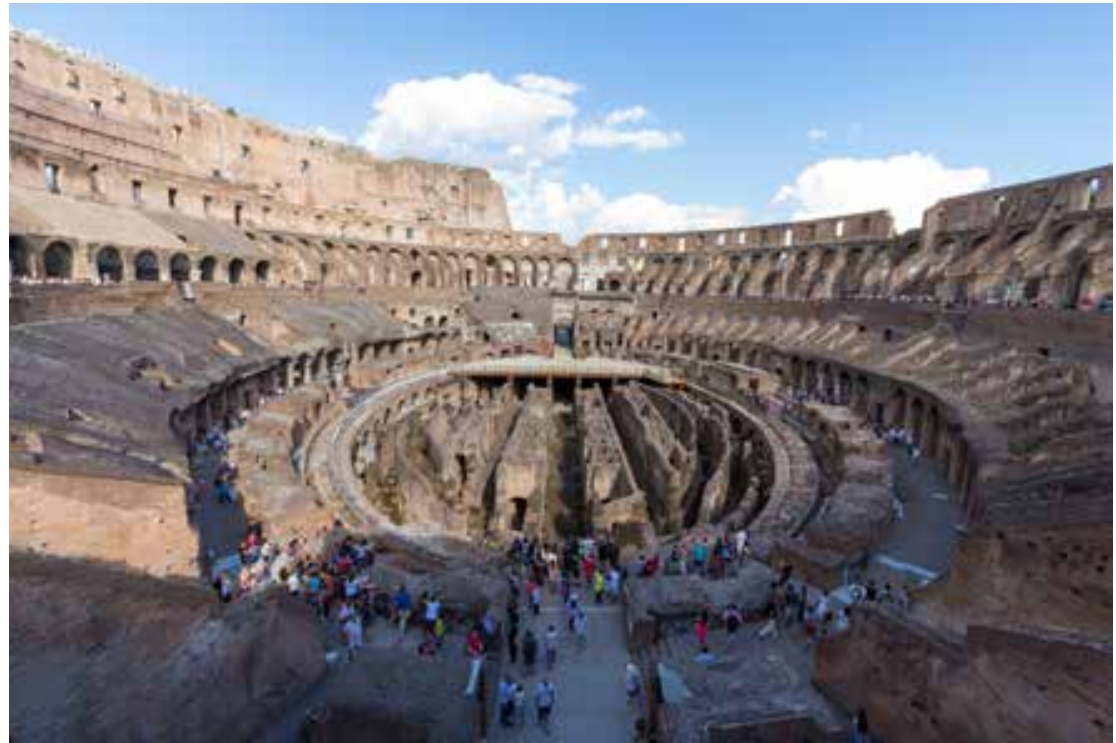

Şekil 10. Roma, Colosseum.

Roma'dan bir diğer örnek ise Colosseum'dan (Şek. 10) ele geçmiştir. İri kristalli grimsi Prokonnesos mermerinden imal edilmiş olan başlık, tıpkı Augustus Forumu başlığında olduğu gibi, Anadolu biçem özelliği göstermektedir. ${ }^{33}$ İşçilikten hareketle başlığın Forum Augustus örneklerine yakın olduğu söylenebilmektedir. Hatta başlığın ölçüleri ve mermer türü de Forum Augustus'un başlıkları ile uyuşmaktadırlar. Destek yaprağı dışında özenli bir işçiliğin varlığı söz konusudur. Leon'a göre Colosseum'da bulunan başlık ile Forum Romanum'da yer alan Bazilika Iulia Korinth başlık gurubu arasında işliğe dayandırılabilecek bir bağlantı söz konusudur. ${ }^{34} \mathrm{Ne}$ var ki yapılışlarına göre değerlendirildiklerinde başlıklar birbirlerinden esaslı bir biçimde ayrılmaktadırlar. Colosseum'da bulunan örnek, çentikli kesilmiş bir akanthus ile bezenmiştir, yaprakları daha geniş ve daha basık çalışılmıştır. Buna karşın Forum Romanum'da yer alan başlık grubunun yaprak dişlerinin uçları yuvarlaktır ve yine yumuşak formlu çukurluklar Roma kentinin taş ustalarının işçilik izlerini taşımaktadırlar. Bu sayede Forum Romanum'un başlıkları daha ince ve zarif bir görünüm kazanmışlardır. ${ }^{35} \mathrm{Bu}$ özellikleri ile Colosseum başlığı Pergamon Traianus Tapınağ başlıklarına benzemektedir. Augustus Forumu başlığı ile olan benzerliğinden yola çıkarak başlı̆ğ Hadrianus dönemine tarihlemek mümkündür. Ancak olasılıkla başlık Colosseum'u tadil ettiren Antoninus Pius döneminde binaya eklenmiş olmalıdır. ${ }^{36}$

33 Freyberger, Stadtrömische Kapitelle, 63, Lev. 19b, 22c.

34 Christoph F. Leon, Die Bauornamentik des Trajansforums und ihre Stellung in der Früh-und Mittelkaiserzeitlichen Architekturdekoration Roms (Böhlau Verlag, 1971), 217, Lev. 86.1.

35 Freyberger, Stadtrömische Kapitelle, 63.

36 Freyberger, Stadtrömische Kapitelle, 63. 


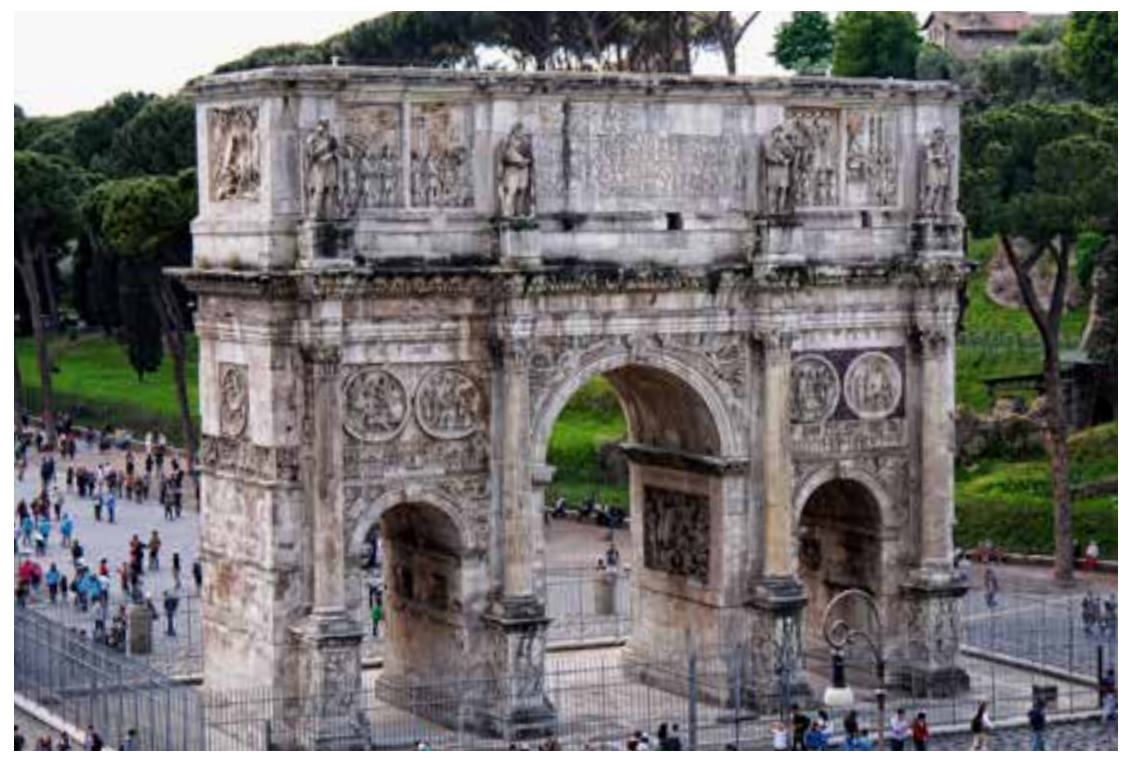

Şekil 11. Roma, Konstantinus Takı.

Roma'dan bir diğer örnek ise Konstantinus Takı'nda yer almaktadır (Şek. 11). Yine iri kristalli grimsi Prokonnesos mermerinden imal edilen başlık, Konstantinus Takı'nı çevreleyen bölümün alt kısmında, devşirme malzeme olarak kullanılmıştır. ${ }^{37}$ Vatikan'da iyi korunagelmiş olan başlıkta belirgin bir biçimde sivri kesmeli akanthus mevcuttur. Keskin kesilmiş kertikler dar ve dik kenar11 yaprak dişlerinin arasından geçmekte ve üst sıra yapraklarını birbirlerinden ayırmaktadırlar. Colosseum ve Forum Augustus'un örneklerinde olduğu gibi Konstantinus Takı sütun başlığı grubu da özel bir form olmak üzere tek bölümlü kaulis düğümünü içermektedir. Söz konusu devşirme başlıklar Roma'da bulunan diğer iki örneğin ve Pergamon'daki Traianus Tapınağı'nın dönemsel biçemine sahiptirler. Bu nedenle Konstantinus Takı başlıklarının Hadrianus dönemine tarihlendirilmesi önerilebilmektedir. ${ }^{38} \mathrm{Bu}$ başlık da diğer örnekler gibi Anadolulu ustaların ellerinden çıkmış olmalıdır. ${ }^{39}$

Roma'da, Hadrianeum olarak anılan yapıda görülen on bir adet Korinth başlığ 1 (Şek. 12) iri kristalli grimsi mermerden imal edilmiş olup, muhtemelen diğer örneklerde olduğu gibi yine Prokonnesos mermerindendir. ${ }^{40}$ Hadrianeum, İmparator Hadrianus'un ölümünden sonra MS 145 yılında törenle açılmıştır.

37 Freyberger, Stadtrömische Kapitelle, 63-65, Lev. 22d; Mark Wilson Jones, Principles of Roman Architecture, 3. Baskı (New Haven: Yale University Press, 2009), 123.

38 Freyberger, Stadtrömische Kapitelle, 63-64.

39 Heilmeyer, Korinthische Normalkapitelle, 167; Leon, Die Bauornamentik, 215; Freyberger, Stadtrömische Kapitelle, 65.

40 Hadrianeum'um bütün mimari bezemelerinde de Prokonnesos mermeri kullanılmıştır. Ancak biçem kritik yolu ile yapılan analojide daha çok sütun başlıkları göz önünde bulundurulmuştur. Bkz. Strong, "Late Hadrianic", 124; Freyberger, Stadtrömische Kapitelle, 65, Lev. $20 a-b, 21 b-c$. 


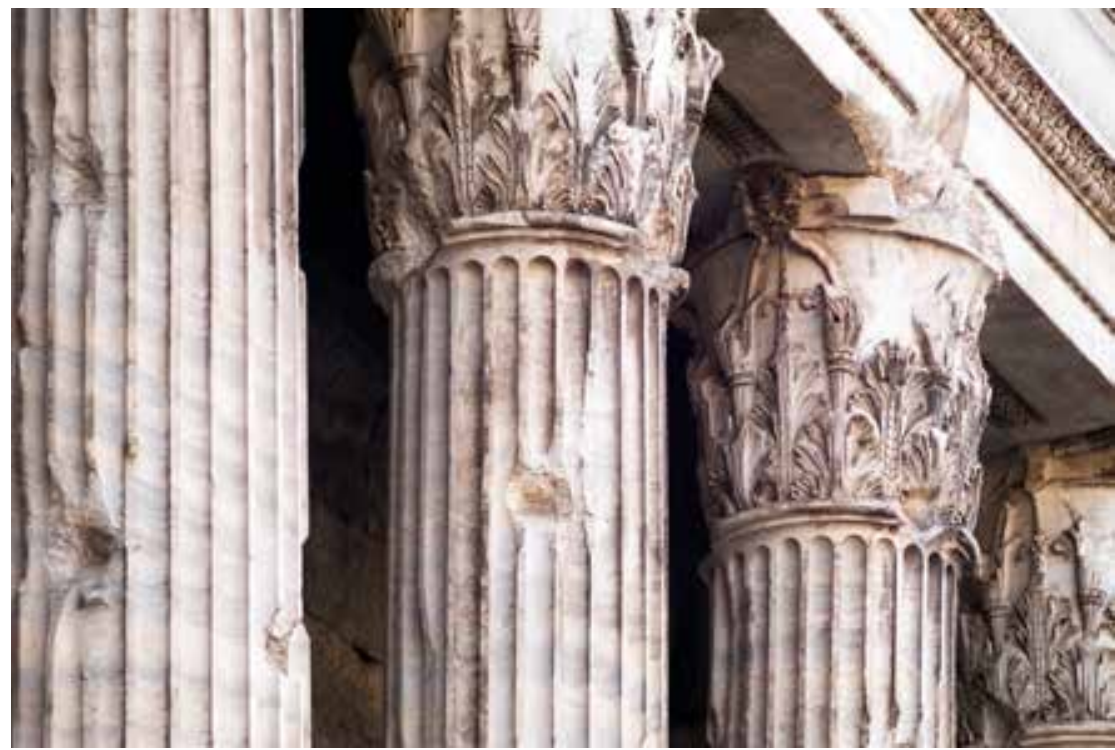

Şekil 12. Roma, Hadrianeum Korinth başlıkları.

Bugün Piazza di Pietra meydanında bulunan borsa binasının arka cephesini oluşturan cella duvarı ve korunagelen 11 sütunun taşıdığı başlıklar daha önce bahsedilen başlıklar gibi Anadolu başlıklarının biçem özelliklerini sergilemektedirler (Şek. 12-13). Gösterdiği ince işçilik nedeniyle özenli bir işin ürünü oldu$\breve{g u}$, dolayısıyla da "pahalı" olarak tanımlanabilecek eserler grubuna girdiğini rahatlıkla söyleyebiliriz. ${ }^{41}$

Yukarıda özelliklerine değinilen Roma kenti başlıklarının hepsinde genel hatları ile bir biçem birliğinden bahsetmek mümkündür. MS I. yüzyıl ve II. yüzyılın ilk yarısında Roma kentinde kullanılan Korinth başlıklarında akanthus yapraklarının kalathos yüzeyinde geniş bir yer kaplaması ve yaprak uçlarının kalathos yüzeyinden ayrılarak plastik bir görünüm alması yerel biçemden daha ziyade “Anadolu Biçemi”ni çağrıştırmaktadır. Yine akanthus yapraklarında yaprakçık dişlerinin derin damarlı ve sivri uçlu olarak işlenmesi, yaprakların derin kanallara ve güçlü damarlara sahip olması gibi özellikler de Anadolu kökenli bir biçemin varlığının kanıtıdır. Buraya kadar anlatılanlardan yola çıkarak yukarıda örneklenen başlıkların malzeme ve biçem yönünden Anadolu'dan ithal edildiği fikri akla yatkın görünmektedir. Ancak her ne kadar mermeri Prokonnesos'dan, yaprak biçemi de Pergamon-Ephesos Bezeme Okulu'ndan olsa da salt bu yönleri ile başlı̆̆ tamamıla Anadolu kökenli olarak tanımlamak yanlış olacaktır. Kaldı ki başlı̆̆ın yaprak detayları dışındaki bezeme unsurları Roma kenti Korinth başlıklarının biçem özelliklerini sergilemektedir. Bu başlıklar olasılıkla bir mimari program dahilinde Roma işliğinde çalışan Anadolulu ustalar tarafından şekillendirilmiş olmalıdır. ${ }^{42}$ 


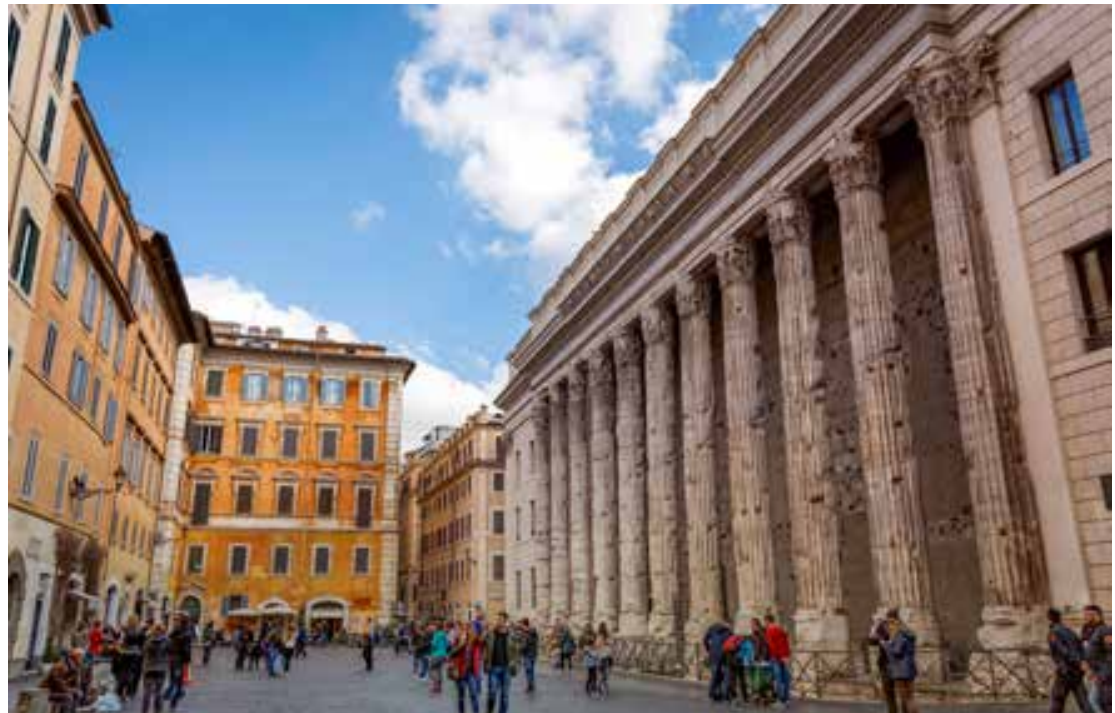

Şekil 13. Piazza di Pietra meydanında yer alan Hadrianeum'un korunagelmiş cella duvarı ve 11 adet Korinth sütunu.

Anadolu mermerlerinin ve işçiliğinin görüldüğü bir diğer önemli bölge Suriye-Filistin bölgesidir. Roma'ya oldukça uzak, kendine has bir sanat geçmişi olan Suriye bölgesi mimari bezeme biçeminin değişimini, gelişimini hatta yeniden uyarlanmasını takip etmek açısından önemlidir. Roma'nın egemenlik sahasını MS I. yüzyılda Suriye-Filistin, Arap yarımadası ve Mısır’a değin genişletmesi ve tüm bu bölgelerde kendi gücünü ve ihtişamını göstermek istemesi sonucunda diğer Akdeniz kentlerinde olduğu gibi bu bölgede yer alan kentleri de bir nevi şantiye alanına çevirmiştir. ${ }^{43}$ Roma'nın severek kullandığı Korinth yapı biçemi Suriye-Filistin bölgesinde yeni bir forma dönüşmüştür. Örneğin Baalbek'de Suriyelilerin yanında Romalıların istihdam edilmiş oldukları bilinmektedir. ${ }^{44} \mathrm{Bu}$ ustalar çalıştıkları projelerde artık belli bir sanatsal düşünceye ya da siyasal mimari bir akıma kendilerini bağlı hissetmemiş, aksine değişen ekonomik gerçeklere uyum sağlamakla beraber çeşitli sanat formlarını aynı binanın içinde, karışık bir biçimde kullanır olmuşlardır..$^{45}$

Bugün İsrail sınırları içerisinde yer alan ve Beth-Shean olarak bilinen Scythopolis antik kenti tiyatrosunda bulunan Korinth başlı̆̆ Pergamon Bezeme Okulu'nun biçemini göstermesi bakımından önemlidir. ${ }^{46}$ Başlığa ait yaprakların biçimi normal Korinth başlı̆̆ı formundadır. Başlığın üst akanthus yaprak sırası alt yaprak sırasının arasında görülen pul biçimli, üç köşeli kaidelerden yük-

43 Pensabene, "Marmi d'Importazione", 275.

44 Heilmeyer, Korinthische Normalkapitelle, 175.

45 Heilmeyer, Korinthische Normalkapitelle, 175.

46 Moshe L Fischer, Das Korintische Kapitell im Alten Israel in der Hellenistischen und Römischen Periode: Studien zur Geschichte der Baudekoration im Nahen Osten (Mainz am Rhein: Philipp von Zabern, 1990), 40, Lev. 8.43. 


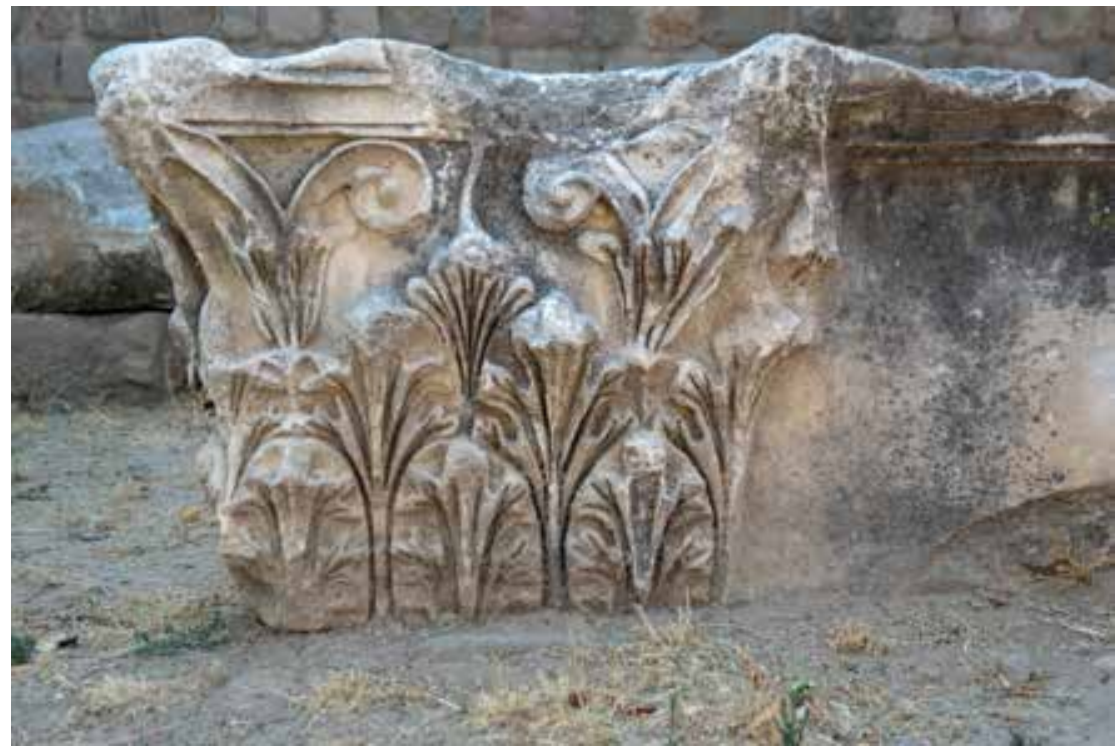

Şekil 14. Pergamon, Kızıl Avlu Korinth pilaster başlığı.

selmektedir. Bu kaideler ise çelenk yaprakları parçaları ile kısmen örtülmüşlerdir. ${ }^{47}$ Üst akanthus yaprak çelenklerinin kalathos kaidesinden yükselmesi nedeniyle yapraklar başlığın büyük bir bölümünü kaplamaktadırlar. Söz konusu yaprakların damarları ise eğik hatlar ile ana damara erişmektedirler. Çanak yapraklar iki yarık hat ile ikiye bölünmüşlerdir. İç çanak yaprakları başlığın üst bölümünde, merkezde birbirleri ile temas etmemekte, fakat üst sıra akanthus yapraklarının üst kısımlarına kadar ulaşmaktadırlar. Heliksler ise volütlerin hemen yaprak çanağının üzerinden ayrılmakta ve kalathos dudağının altında açık bir spiralin içine doğru kıvrılmaktadırlar. Volütlerin üst yüzeyleri nispeten düzdür. Heliksler zayıf bir biçimde vurgulanmış olan bir kanala sahiptirler. Birbirlerinden kesin hatlar ile ayrılmış dört adet yapraktan oluşan sapsız abakus çiçeği, abakus levhasının cephesinin ortasında yer almaktadır. ${ }^{48}$ Scythopolis kenti örneklerine bakıldığında ilk örneklerini Pergamon Traianus Tağınağı́nda olduğunu ve Kızıl Avlu'dan bilinen bir modeli takip ettiğini görmekteyiz (Şek. 14). Başlıkların biçemi Pergamon-Ephesos Bezeme Okulu'nun biçemini yansıtması nedeniyle bu başlıkların ithal ürünler olduğu düşünülmektedir. ${ }^{49}$

\section{Aphrodisias Bezeme Okulu}

MS II. yüzyılın ortalarında Aphrodisias Bezeme Okulu'nun eser vermesine değin Pergamon-Ephesos Bezeme Okulu, Anadolu ve diğer eyaletlerde yürütülen imar faaliyetlerinde mimari süsleme konusunda etkili olmuştur. Helenistik dönemden beri heykeltıraşlık konusunda etkin olduğu bilinen Aphrodisias Beze-

47 Fischer, Das Korintische, 40, Dnt. 377.

48 Fischer, Das Korintische, 40.

49 Strong, "Late Hadrianic", 131-133; Heilmeyer, Korinthische Normalkapitelle, 88-92; Leon, Die Bauornamentik, 236-237; Fischer, Das korintische, 40. 


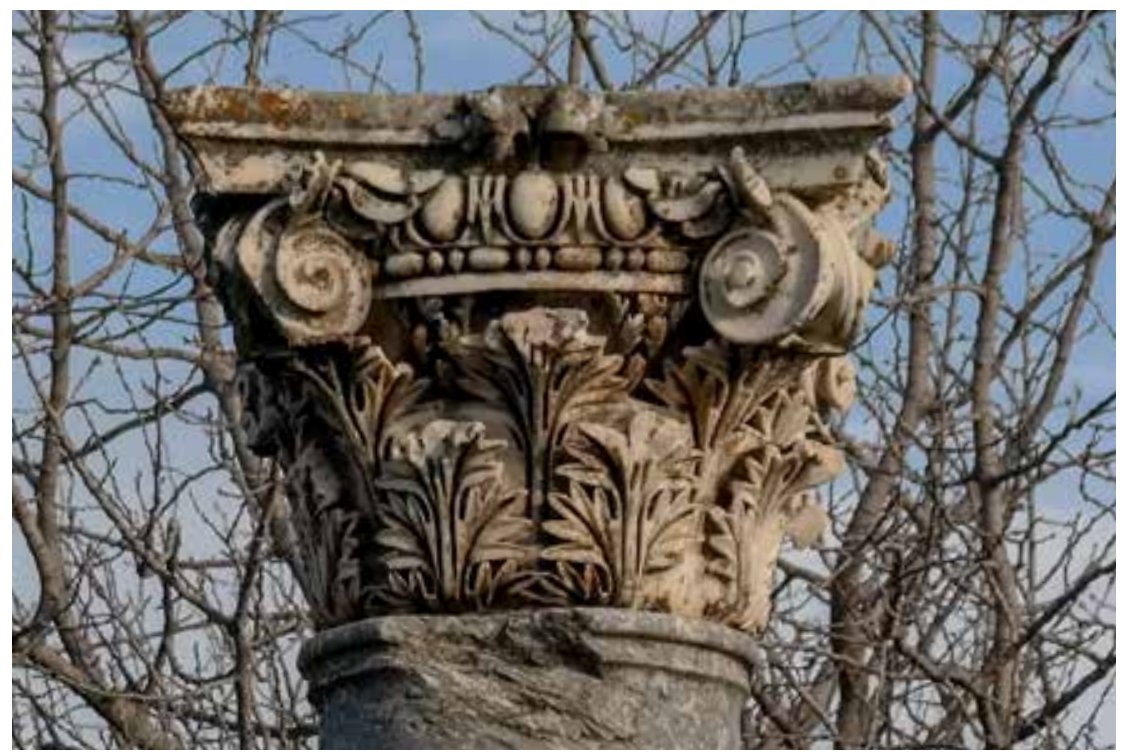

Şekil 15. Aphrodisias, Bazilika A kompozit başlı̆̆ı.

me Okulu, MS II. yüzyılın ikinci yarısından sonra Roma İmparatorluk sınırlar1 içinde yürütülen hemen hemen bütün imar faaliyetlerinde mimari bezeme konusunda tekelleşmeye başlamıştır. Roma'dan Suriye'ye, Filistin'den Kuzey Afrika'ya kadar geniş bir coğrafyada Aphrodisias Bezeme Okulu'nun biçem özelliklerini MS II-III. yüzyıl yapılarının birçoğunda görmek mümkündür.

MS II. yüzyılın ikinci yarısına ait olan ve Bazilika A olarak adlandırılan yapıda $^{50}$ bulunan kompozit başlıklar ${ }^{51}$ (Şek. 15) genel görünümleri ile basık ve geniştirler. Başlık yüzeyini kaplayan akanthus yapraklarının kalathosun basık yapılması nedeniyle yayvanlaştığı, daha önceki örneklerde gördüğümüz, yapraklar arasında yer alan boşlukların bu yayvanlaşma sonucunda yaprak uçlarının birbirlerine değmesi nedeniyle kapandığı görülmektedir. ${ }^{52}$ Üst sıra akanthus yaprakları alt sıra akanthus yapraklarının arasındaki kalathosun taş yüzeyinden filizlenirler. Bu başlığın ekhinusunu inci dizisi ve derince oyulmuş Ion kymationu süslemektedir. Ekhinus geniş̧̧e yuvarlak bir kavis yaprak öne doğru çıkar ve altında düzgün bir profil gösteren kalathos dudağı bulunur.

50 Lutgarde Vandeput, The Architectural Decoration in Roman Asia Minor. Sagalassos: A Case Study (Leuven: Brepols, 1997), 39; Aphrodisias Tiyatrosunun güneyinde yer alan "Bazilika A" ya da "Gaudin'in Gymnasiumu" olarak anılan yapı orijinalinde büyük bir Roma evinin peristilidir. İlk kazıları yapan Fransız demiryolu mühendisi Paul Gaudin tarafından Gymnasium olarak tanımlanan yapı, bilinmeyen bir tarihte üzeri kapatılarak kiliseye dönüştürülmüş ve bu dönüşüm nedeniyle de Bazilika olarak tanımlanmıştır. Bkz. Örgü Dalgıç, "Early Christian and Byzantine Churches", Aphrodisias V, The Aphrodisias Regional Survey içinde, der. Christopher Ratté ve Peter de Staebler (Darmstadt/Mainz: Verlag Philipp von Zabern, 2012), 371, Dnt. 17; Esen Öğüş, "A Late-antique Fountain at Aphrodisias and Its Implications for Spoliation Practices", Journal of Roman Archaeology 28 (2015): 303.

51 Heilmeyer, Korinthische Normalkapitelle, 98, Lev. 32. 1, 2; İdil, “Anadolu'da Roma," 27, Lev. 12, 4; 13, 1, Dnt. 83; Başaran, Anadolu Kompozit, 29; Vandeput, The Architectural, 173.

52 Başlığın akanthus yapraklarının biçemi, Ephesos Liman Caddesi'nde bulunan bir kompozit başlık (EFES 5A) ile paralellik göstermektedir. Bkz. Başaran, Anadolu Kompozit, 29, Resim 26. 


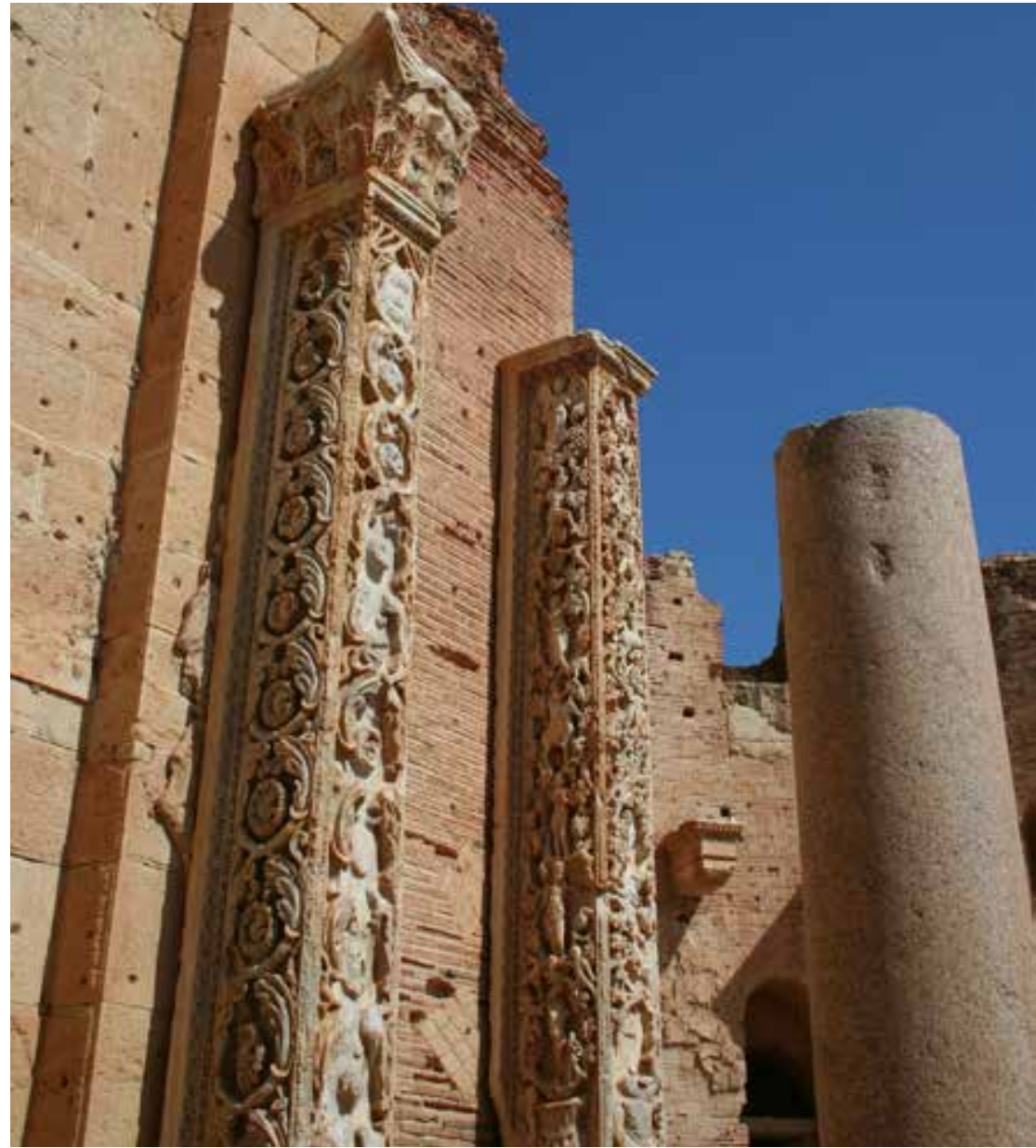

Şekil 16. Leptis Magna, Severus Bazilikası mermer pilasterleri figürlü sarmal dal bezemeleri.

Kalathosun üst kesiminde, dudağının altında bulunan boşluğa zambak biçimli bitki bezekleri işlenmiştir. Volütler geniş kanallıdırlar ve bunların iç köşelerinden çıan ve her biri üçer yapraktan oluşan palmet çiçekleri ise ekhinusu süsleyen Ion kymationuna kadar uzanmaktadır. Abakus levhasının ortasında abakus çiçeğine de yer verilmiştir. ${ }^{53}$ Bazilika A yapısında görülen bu başlık tipi Aphrodisias Bezeme Okulu'nun biçemini yansıtması açısından önemlidir. MS II. yüzyılın ikinci yarısından itibaren bu başlık tipi hemen hemen bütün Roma kentlerinde görülen başlık tipi olacaktır.

Asia Eyaleti, özellikle de Batı Anadolu kentlerinde MS II. yüzyıl başından beri mimaride yaşanan hızlı dönüşüm ivmesini MS II. yüzyıl sonu ile III. yüzyıl başından itibaren kaybetmeye başlamıştır. Bu dönemin hemen sonrasında doğu eyaletlerinde yaşanan siyasi gerilimler ve savaşların ardından Roma İmparator-

53 Heilmeyer, Korinthische Normalkapitelle, 98; İdil, "Anadolu'da Roma", 27-28. 


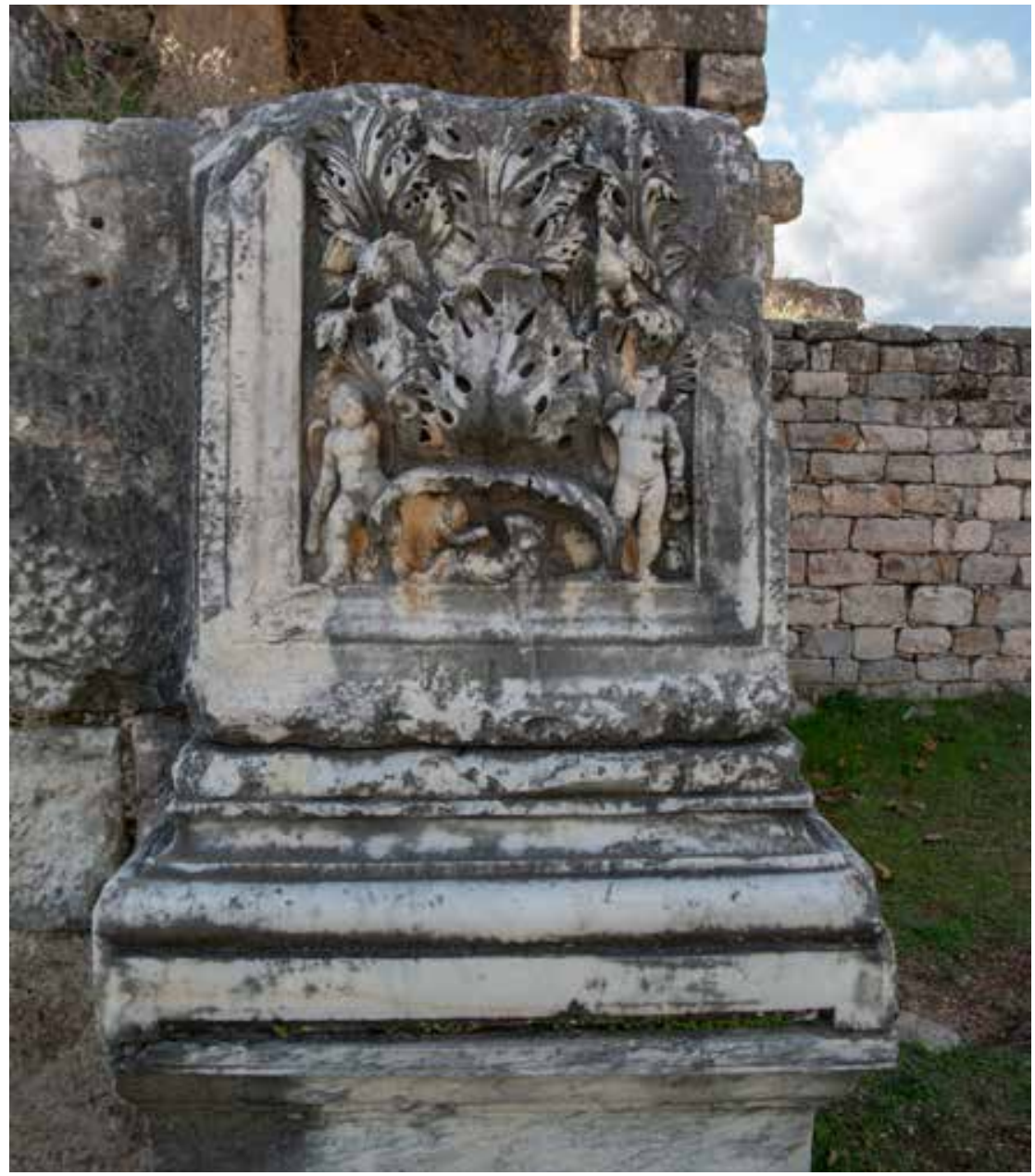

Şekil 17. Aphrodisias, Hadrianus Hamamı pilasteri sarmal dal bezemesi.

luğu gücünü yeni kurulan ya da yeniden imar edilen kentlerde yürüttüğü imar faaliyetleri ile göstermiştir. Bu projelerin hayata geçmesi ile yaşanan hammadde ve usta sıkıntısını, yine Roma'da olduğu gibi, Anadolu'da işletilen mermer ocakları ve eser veren bezeme okullarının hammadde ve usta ihraç etmesi ile aşmışlardır.

Leptis Magna Kuzey Afrika kentleri arasında en iyi korunmuş ve günümüze değin en iyi araştırılmış Roma kentlerinden biridir. Libya sınırları içerisinde yer alan kentte, Roma İmparatoru Septimius Severus'un (MS 145-211) doğum yeri olması nedeniyle gerek Septimius Severus'un imparatorluk yıllarında (MS 193211) gerek Severuslar hanedanının iktidarda kaldığı dönemlerde (MS 193-235) önemli imar projeleri yürütülmüştür. Leptis Magna'da yer alan birçok yapıda Anadolu kökenli mermer ve mimari bezeme biçemini görmek mümkündür.

Aphrodisias ve Leptis Magna'daki heykeltıraşlık eserlerinin birbirlerine çok yakın ilişkide olduğu tartışma götürmez bir gerçektir. Örneğin Hadrianus dö- 


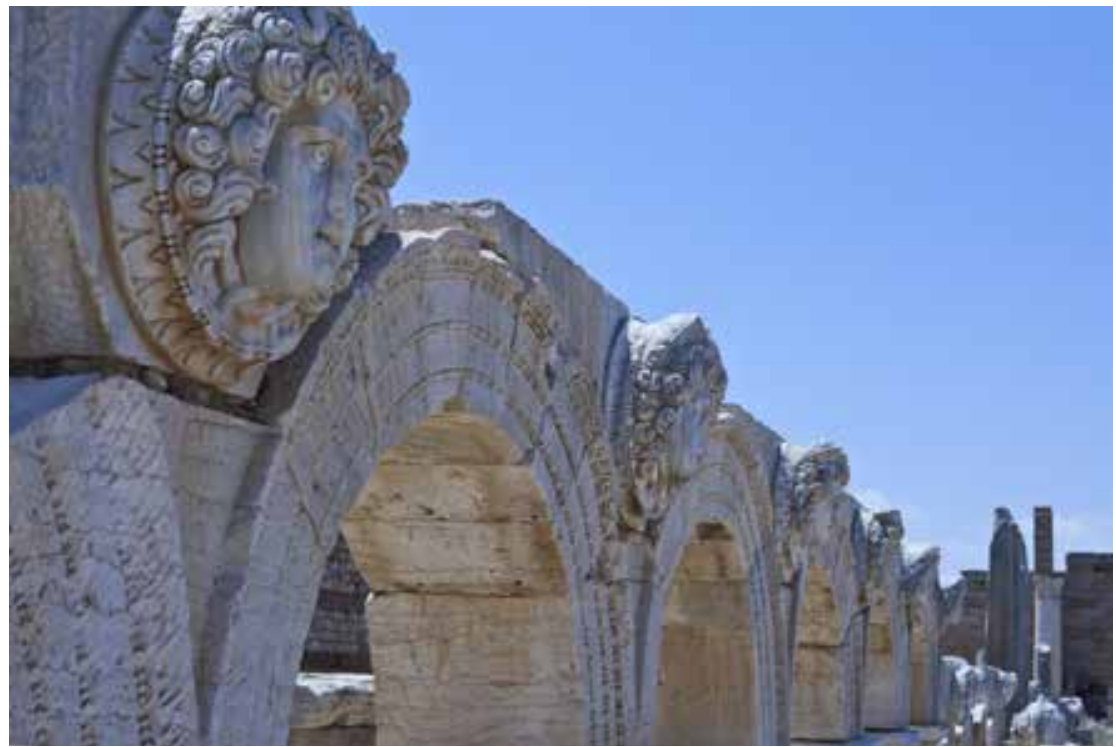

Şekil 18. Leptis Magna, Forum Portikoları'nı süsleyen Gorgo ve Nereid madalyonları.

neminden itibaren Küçük Asya'dan mermer yapı malzemesi ithal eden Leptis Magna'da Severus Bazilikası'nın mermer pilasterleri üzerinde görülen figürlü sarmal dal bezemeleri (Şek. 16), Aphrodisias Hadrianus Hamamı pilasterleriyle (Şek. 17) biçem yönünden büyük benzerlik göstermektedir. ${ }^{54} \mathrm{Bu}$ benzer öğeleri Leptis Magna Forum Portikoları'nı süsleyen Gorgo ve Nereid madalyonları (Şek. 18), Aphrodisias Hadrianus Hamamları Medusa ve Minotauros süslemelerinde de görmek mümkündür. ${ }^{55}$ Ayrıca Leptis Magna'da birçok yapının Korinth başlıklarının Prokonnesos mermerinden yapıldığı ve bu başlıkların biçeminin Anadolu kökenli olduğu bilinmektedir. ${ }^{56}$ Bu nedenle Leptis Magna'daki Severus dönemi yapılarında Aphrodisiaslı ustaların çalıştığı düşünülmektedir. ${ }^{57}$

MS II. ve III. yüzyıllarda, mimari bezemeye hâkim olan Aphrodisias Okulu'nun, kentlerde yürütülen imar faaliyetleri için yarı işlenmiş hammadde ve usta temin ettiği bilinmektedir. ${ }^{58}$ MS II. yüzyılın ortalarından itibaren Aphrodisias Bezeme Okulu ustalarının Suriye-Filistin Bölgesi'nde çalışmaya başlamasıyla ${ }^{59}$ bölge kentlerinde Aphrodisias Bezeme Okulu'nun eserleri görülmeye başlanır. ${ }^{60}$ Bu bölgede tercih edilen biçemin Anadolu biçemi olmasında Aphrodisias işlik-

54 Ward-Perkins, “Nicomedia”, 65-66.

55 John Bryan Ward-Perkins, "Severan Art and Architecture at Lepcis Magna", The Journal of Roman Studies 38, no 1 ve 2 (1948), 74.

56 Patrizio Pensabene, "Pentelico e Proconnesio in Tripolitania: Coordinamento o Concorrenza Nella Distribuzione?", Archeologia Classica XLIX (1997), 275-422.

57 Ward-Perkins, “Nicomedia", 64-67; Ward-Perkins, “Tripolitania”, 89-104.

58 Fischer, Das Korintische, 36; Pensabene, "Marmi d'Importazione", 276.

59 Fischer, Das Korintische, 36; Pensabene, "Marmi d'Importazione", 276.

60 Pensabene, "Marmi d'Importazione”, 275-76; Deniz Kaplan, "Korykos Antik Kentinin ve Kilikia Bölgesinin Korinth Sütun Başlıkları”, Olba XIV (2006), 104-105. 
lerinin çok sayıda başlık üretme kabiliyeti de etkili olmuştur. ${ }^{61}$ MS II. yüzyılın son çeyreğinde, Korinth başlıklarında, alt sıra akanthus yaprak çelenklerinin alt yaprak dişlerinin yanı sıra orta yaprak dilimi yaprak dişlerinin de komşu yaprak dişleri ile birleştiği görülmektedir. ${ }^{62}$ Geç Helenistik Dönem'den başlayarak ${ }^{63}$ Suriye Korinth başlıklarında görülen bu tarz işçilik, MS II. yüzyılın ortalarından itibaren Suriye-Filistin Bölgesi'nde çalışmış olan Aphrodisias Bezeme Okulu ustaları tarafından da benimsenmiştir. ${ }^{64}$ Roma İmparatorluk sınırları içerisinde MS II. yüzyılın sonu III. yüzyılın başına tarihlenen büyük merkezlerde yürütülen projelerde Aphrodisias Bezeme Okulu ustalarının bu biçemi yoğun bir şekilde kullandığı görülmektedir. ${ }^{65}$

Suriye söz konusu olduğunda Anadolu biçeminin bir değişim geçirdiği görülmektedir. Helenistik dönemden beri özgün bir mimari bezeme geleneğine sahip olan Suriye kentlerinin, MS II. yüzyıldan itibaren Roma'nın biçem hâkimiyetine tam anlamıyla girmediği, kendine has bir tip özelliği yarattığını söylemek mümkündür. ${ }^{66}$ Özellikle Aphrodisias Bezeme Okulu'nun etkisi ile şekillenen bu biçem doğu eyaletlerinde sevilerek kullanılmış ve hatta Anadolu'nun güney kıyılarında yer alan kentlerde de kendine yer bulabilmiştir.

Suriye Aş-Şanamain'daki, yazıtı ile MS 191/192 yıllarına kesin tarihlenen Tykhe Tapınağı'nın başlıkları Aphrodisias Bezeme Okulu etkisi ile şekillendirilen başlıklar arasında gösterilebilir. ${ }^{67}$ Başlık yüzeyini kaplayan akanthus yapraklarının sivriltilmiş uçlarının birbirine değmesi nedeniyle başlık yüzeyinin sıkışık bir kompozisyona sahip olması da bu dönem biçem özellikleri arasındadır. Suriye'de yer alan bir diğer Aphrodisias Bezeme Okulu örneği ise Bosra tiyatrosu Korinth başlıklarıdır (Şek. 19). Tipkı Aş-Şanamain Tykhe Tapınağı́nda olduğu gibi Bosra Tiyatrosu başlıklarında da akanthus yaprakları tüm başlık yüzeyini kaplamaktadır. ${ }^{68}$

İsrail sınırları içerisinde yer alan Caesarea'da bulunmuş olan figürlü bir başlık bu yönü ile Aphrodisias Bezeme Okulu biçemini sergilemektedir. ${ }^{69}$ Başlık cephelerinden birinde, abakus çiçeğinin yerine başında sur tacı takılı halde betimlenen Tykhe figürü yapılmışken, diğer cephelerde normal Korinth başlıklarında olduğu gibi abakus çiçeği motifleri görülmektedir. ${ }^{70}$ "Figürlü Başlıklar" tanımı içerisine giren bu başlık tipi ve beraberinde kullanılan bitkisel motiflerin kompozisyonu dönem biçemi göz önünde bulundurulduğunda olağan karşı-

61 Mosche L. Fischer, Marble Studies: Roman Palestine and the Marble Trade (Konstanz: UVK Universitätsverl, 1998), 67.

62 Heilmeyer, Korinthische Normalkapitelle, 99-100; Freyberger, Stadrömische, 128; Pensabene, "Marmi d'Importazione", Fig. 160-161; Kaplan, "Korykos Antik", 105.

63 Fischer'e göre Suriye-Filisitin bölgesinde Anadolu biçeminin kullanımı, kanıtlaması zor olsa da, Geç Helenistik, Erken Roma döneminde başlamıştır. Fischer, Marble Studies, 67.

64 Pensabene, “Marmi d'Importazione”, 276; Kaplan, “Korykos Antik”, 105.

65 Heilmeyer, Korinthische Normalkapitelle, 97; Vedat İdil, “Anadolu'da Roma", 29; Fischer, Das Korintische, 36; Kaplan, "Korykos Antik", 105.

66 Fischer, Marble Studies, 67.

67 Klaus S. Freyberger, "Das Tychaion von as-Şanamain. Ein Vorbericht", Damaszener Mitteilungen 4 (1989), 87.

68 Klaus S. Freyberger, "Zur Datierung des Theaters in Bosra", Damaszener Mitteilungen 3 (1988): 17-26, Lev. 9-15; Pensabene, “Marmi d'Importazione”, 373-378.

69 Fischer, Das Korintische, 42, Lev. 10.51a-b.

70 Fischer, Das Korintische, 42. 


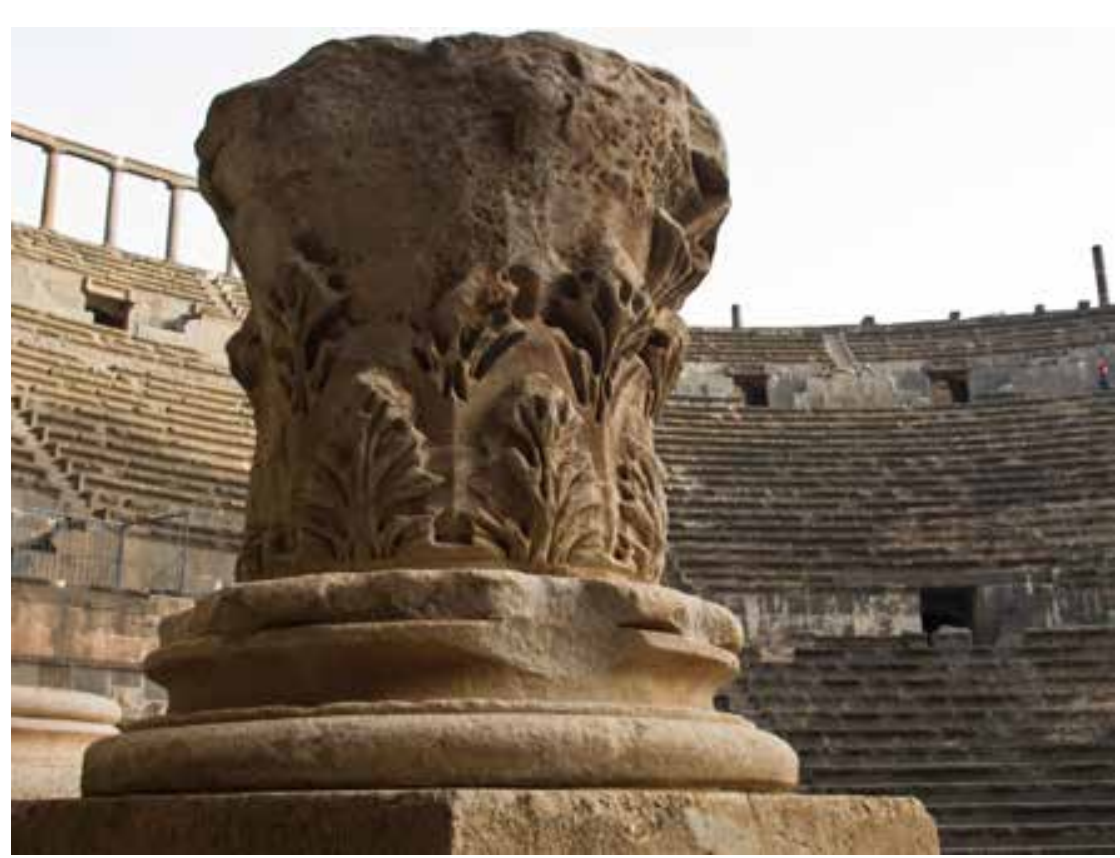

Şekil 19. Suriye, Bosra Tiyatrosu Korinth başlı̆̆1.

lanabilir. ${ }^{71}$ Ancak bu başlık özelinde değerlendirilecek olunduğunda, abakus levhasının üzerinde duran figürün yöreye has bir tasvir karakterini içinde barındırması nedeniyle, başlığın her iki biçeme de hâkim olan ustalarca tasarlandığını, fakat son işlemeyi yerel zanaatkârların yaptığını söylemek mümkündür. ${ }^{72}$

Beth Shean'da bulunan iki adet başlık çelenk yapraklarının orta yaprak parçasının dört dişli, abaküs çiçeğinin abakus levhasının alt kenarına kadar ulaşması ve abakus levhasının zayıf olan başka bir çiçek sapı ile desteklenmesi gibi özellikleri nedeniyle Aphrodisias Bezeme Okulu'nun biçem özelliklerini göstermektedirler. ${ }^{73}$

\section{Sonuç}

MÖ I. yüzyıldan itibaren İmparatorluk sınırları içerisinde yaşanmaya başlayan refah çağı ekonomik kalkınma ile beraber hızlı imarlaşmayı da beraberinde getirmişti. Roma'nın Cumhuriyet yıllarında geleneksel mimari malzemesi olan tuğlanın yerini mermerin alması da aynı döneme denk gelmiştir. İmparatorluk projelerinde ve özel mülklerde ihtiyaç duyulan mermer, hammadde olarak rahatlıkla sağlanabilse de, mermeri işleyecek ustaların sayıca azlığı Helenistik dönemden beri Batı Anadolu'da faaliyet gösteren bezeme okullarına rağbeti arttırmıştır. Roma'da ve eyaletlerde yürütülen imar faaliyetlerinde, Pergamonlu, Ephesoslu ve Aphrodisiaslı ustalar, kendi biçemleri ile yerel biçemleri harmanlayarak yeni bir biçem oluşmasına sebep olmuşlardır.

71 Severuslar döneminde barok özellikli Korinth başlıklarının figürler ile dekore edilmesi alışılmış bir uygulamaydı. Bkz. Nancy L. Hirschland, "The Head-Capitals of Sardis", Papers of the British School at Rome 35 (1967), 22.

72 Fischer, Das Korintische, 42; Pensabene, “Marmi d'Importazione”, 276-278.

73 Fischer, Das Korintische, 42, Lev. 10. 54-55. 
İmparatorluğun başkenti Roma'da Anadolu kökenli biçemin kullanıldığ1 mimari öğeleri görmek mümkündür. Prokonnesos mermerinden imal edilen Korinth başlıklarında, başlık öğelerinde genel şablona bağlı kaldıkları, fakat yaprak biçemlerinde Anadolu biçemini kullandıkları görülmektedir. Bu nedenle de Roma'da çalışan salt Anadolu biçeminde eserler veren bir mimari bezeme okulunun varlığından söz etmektense; mevcut bezeme okullarında çalışan Anadolulu ustaların varlığını kabul etmek daha doğru olacaktır. ${ }^{74}$ Her ne kadar başlıklarda görülen biçemi "Anadolu Biçemi" olarak adlandırsak da başlıkları tamamıyla özgün Anadolu başlıkları olarak tanımlamak mümkün değildir. Roma'da var olan biçemden belirgin bir şekilde ayrılan Anadolu biçeminde eser veren taş ustaları önemli yapı programlarına dahil olmuşlar ve her iki biçemi harmanlayarak yeni bir tip ortaya çıkarmışlardır. Anadolulu taş ustaları ürünlerini ve modellerini imar projelerinin taslaklarına göre üretmişler, fakat yaprak dilimlerini kendi işlik formlarına göre biçimlendirmişlerdir.

Öte yandan Kuzey Afrika eyaletlerinde görülen Anadolu kökenli mermerlerin büyük oranda Anadolu bezeme okullarının, özellikle de Aphrodisias Bezeme Okulu biçemine sadık kalınarak şekillendirildiği görülmektedir. Bu yönü ile bahse konu mimari öğelerin yarı işlenmiş olarak ithal edildikleri, son şeklinin ise şantiye alanında Aphrodiasiaslı ustalar tarafından verildiği kabul edilmelidir.

Suriye-Filistin bölgesi göz önünde bulundurulduğunda, Anadolu mermer ocaklarından ve bezeme okullarından ithal Korinth başlıklarından söz etmek mümkündür. Ancak, Suriye özelinde bakılacak olduğunda, girişilen imar projelerinin büyüklüğü ve yapım süreleri nedeniyle ithal ürünlerin kullanılmasindansa, ithal taklidi ürünlerin kullanılması zorunluluğu doğmuştur. ${ }^{75} \mathrm{Bu}$ noktada Anadolu bezeme okullarında çalışmış olan ustalar ve bunlarla birlikte çalışan yerli ustaların yerel kireç taşından ürettiği eserlerin varlığından söz etmek mümkündür. İsrail ve Filistin bölgesinde ise; ithal edilen mermerin büyük oranda Anadolulu bezeme okullarının ustaları tarafından şekillendirildiği, fakat önemli ölçüde de yerel mermer ve kireç taşının Anadolulu bezeme okulları etkisinde eserler veren ustalar ve bunların etkisinde eser veren yerel ustalarca işlendiğini söylemek doğru olacaktır.

Suriye'de çalışan Anadolulu ustalar ile birlikte yeni, kompozit bir mimari biçemin ortaya çıktığını söylemek ve Kilikia Bölgesi başta olmak üzere Anadolu'nun güneyinde yer alan birçok kentte bu etkiyi görmek mümkündür. MS II. ve III. yüzyıllarda yeni kurulan ya da yeniden imar edilen birçok kentte, kentlerin ana eksenini sütunlu caddeler oluşturmaktaydı. Kent planlamasında önemli bir unsur olarak karşımıza çıkan sütunlu caddelerin daha çok doğu kentlerinde kendisine yer bulmasıyla doğu ile özdeş tutulması sonucu ortaya çıkmıştır. ${ }^{76}$ Yaşadığı mekânları mozaik ve duvar resimleri ile süslemeyi seven Romalılar, sütunlu cadde gibi büyük ölçekli yapıları da imparator, senatör ya da vali heykellerinin yanı sıra tanrı, tanrıça, yarı tanrı ve mitolojik kahramanların var olduğu plastik eserlerle süsleyerek dönemin estetik anlayışını yansıtmışlardır.

74 Freyberger, Stadtrömische Kapitelle, 67.

75 Fischer, Das Korintische, 47.

76 Warwick Ball, Rome in the East: The Transformation of an Empire (London: Routledge, 2000), 266. 


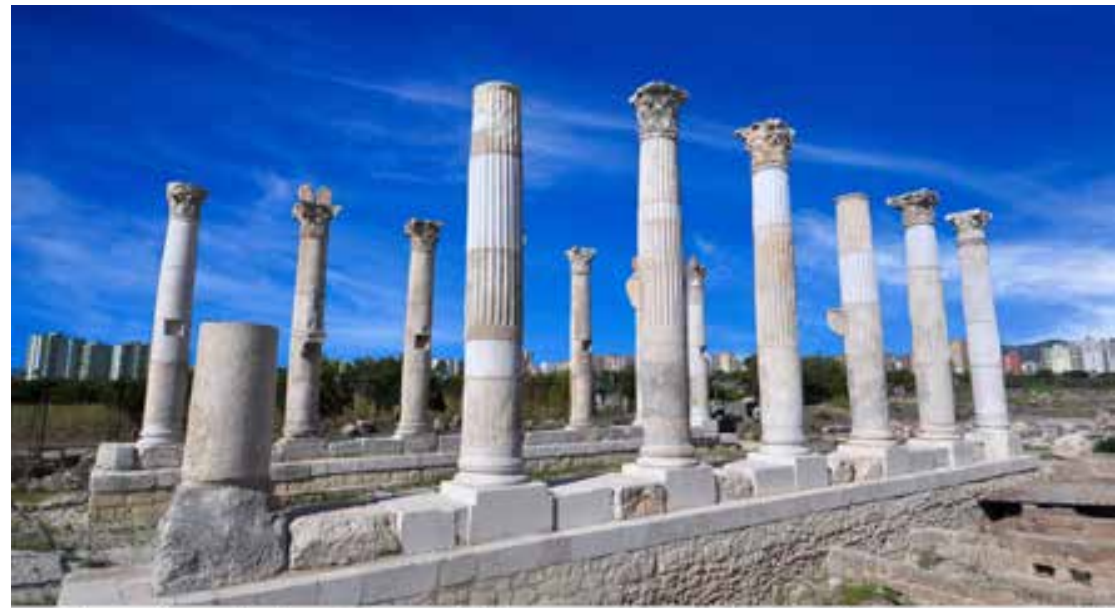

SOLI/POMPEIOPOLIS SŨTUNLU CADDESI GÛNEY UCU BATI PORTIKO YENIDEN KURMA DENEMESI

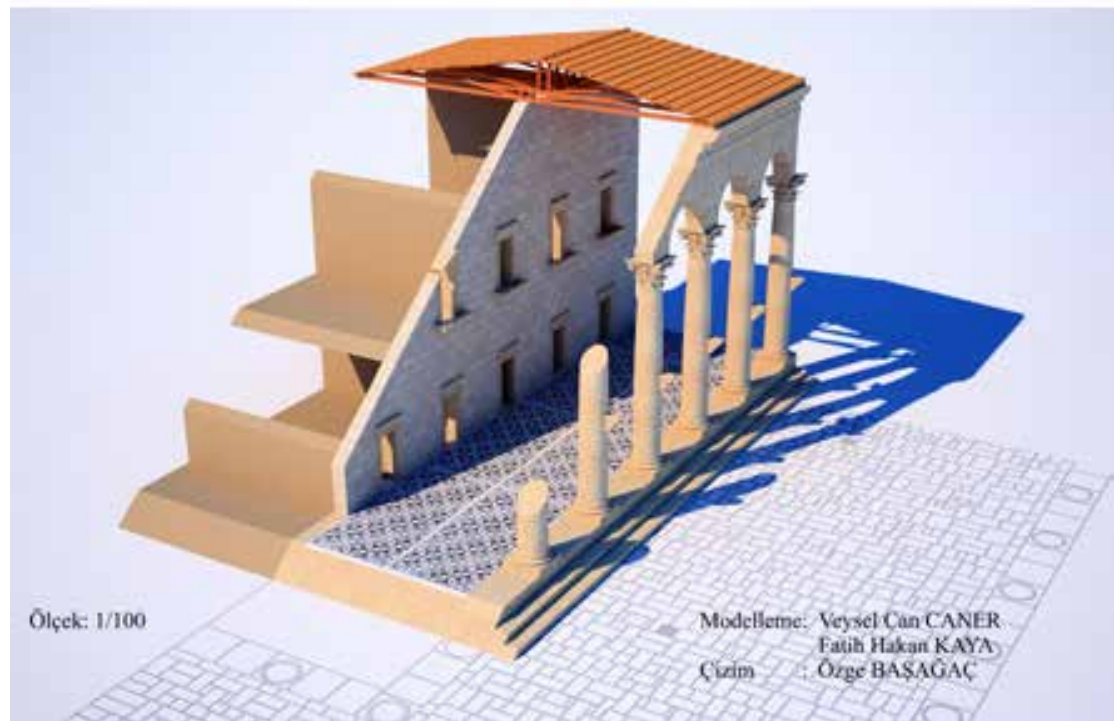

Şekil 20. Soli-Pompeiopolis Antik Kenti Sütunlu Caddesi.

Sütunlu caddelerin heykel galerilerine dönmesini sağlayan ise Suriye kökenli bir eklentidir ${ }^{77}$ ve sütun konsolları olarak adlandırılan bu eklenti Suriye kentlerinde, birçok sütunlu caddede görülebilmektedir (Şek. 20). Sütunlar üzerine inşaat sırasında ya da ihtiyaca göre sonradan eklenen konsollar $^{78}$ bu heykellere

77 Anneliese Peschlow-Bindokat, "Zur Säulenstraße von Pompeiopolis in Kilikien”, Istanbuler Mitteilungen 25 (1975), 378; Giorgio Bejor, Vie Colonnate. Paesaggi Urbani Nel Mondo Antico, Rivista Di Archeologia, Suppllementi 22 (Roma: Giorgio Bretschneider, 1999), 70-72; Mükerrem (Usman) Anabolu, İstanbul ve Anadolu'daki Roma Imparatorluk Dönemi Mimarlı Yapitları (İstanbul: Arkeoloji ve Sanat Yayınları, 2001), 13; Şahin Yıldırım, "Soloi-Pompeipolis Liman Caddesi", Güneş Karadeniz'den Doğar. Sümer Atasoy'a Armă̆an Yazılar içinde, der. Şevket Dönmez (Ankara: Hel Yayınları, 2013), 466.

78 Ross Burns, Origins of the Colonnaded Streets in the Cities of the Roman East (New York: Oxford University Press, 2017), 276. 

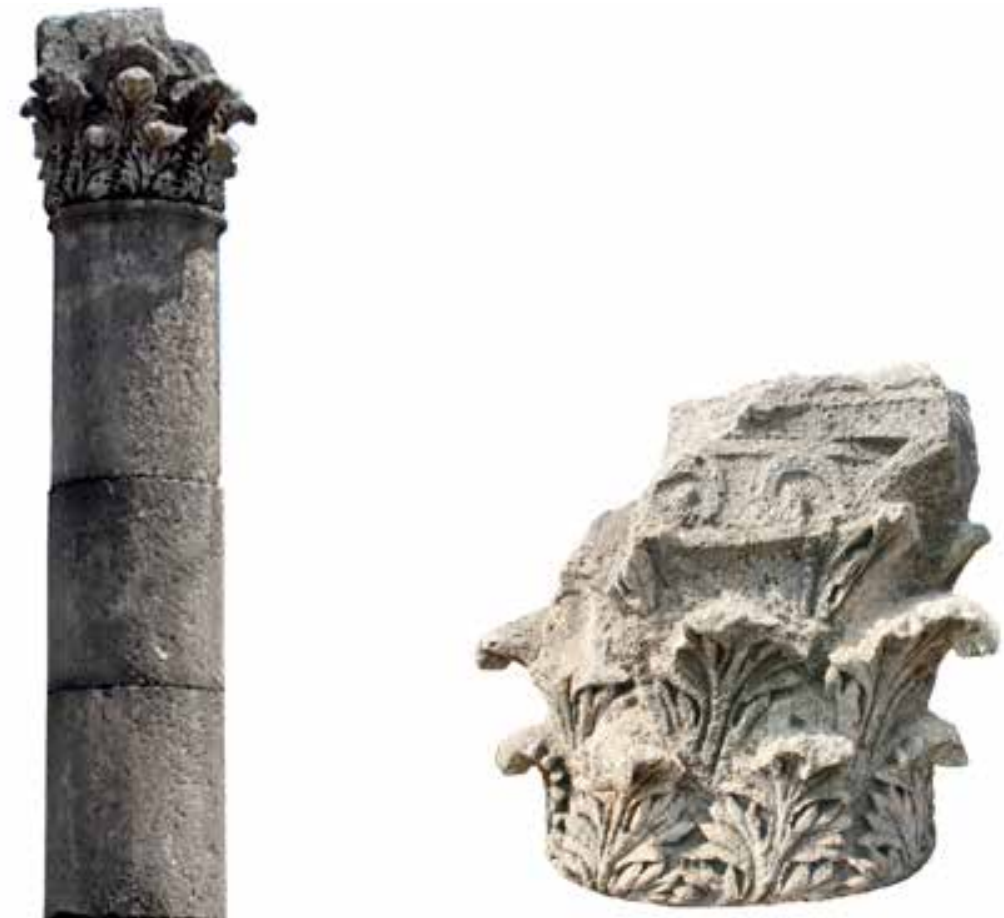

Şekil 21. Soli-Pompeiopolis, Rüzgârda Sallanan Akanthus Yaprağı bezemeli Korinth başlı̆̆1.

kaide işlevi görmüşlerdir. ${ }^{79}$ Palmyra kentindeki sütunlu caddede sütun konsolları şehrin ünlü kişilerinin heykellerini taşımaktayd $1 .{ }^{80}$ Konsollu sütunların Anadolu'daki örnekleri coğrafi olarak Suriye'ye yakın olan Kilikia'da; Anazarbos, Hierapolis-Kastabala, Soli/Pompeiopolis ve Diokaisareia kentlerinde görülebilmektedir. ${ }^{81}$ Yine örneklerine Kilikia-Soli-Pompeiopolis; Pamphylia-Perge ve Phrygia-Hierapolis kentlerinde rastladığımız “Rüzgârda Sallanan Akanthus Yaprağı" olarak tanımlanan yaprak biçemi de (Şek. 21) Suriye kökenlidir. ${ }^{82}$ Sütunlardaki konsol eklentileri ve rüzgârda sallanan akanthus yaprak biçemi gibi yenilikler göz önünde bulundurulduğunda Anadolulu taş ustalarının Suriye'ye taşımış olduğu sanatın değişime uğrayarak tekrar Anadolu'ya geldiği söylenebilir. Bu biçem özellikleri nedeniyle "Suriye Tipi" olarak tanımlanan mimari bezeme öğelerinin yaratıcıları, olasılıkla Anadolulu ustalar ile çalışan ve özgün eserler veren yerel ustalar olmalıdır.

79 J. Stephens Crawford, The Byzantine Shops at Sardis, Monograph / Archaeological Exploration of Sardis: 9 (Cambridge, Mass.: Harvard University Press, 1990), 114.

80 Ian A. Richmond, "Palmyra under the Aegis of Rome", The Journal of Roman Studies 53, no 1-2, (1963), 43-54; Stephen Mitchell ve diğerleri, Cremna in Pisidia: An Ancient City in Peace and in War (London: Duckworth, 1995), 137-138.

81 Peschlow-Bindokat, "Zur Säulenstraße”, 378; Bejor, Vie Colonnate, 70-72; Anabolu, İstanbul ve Anadolu'daki, 13; Yıldırım, "Soloi-Pompeipolis", 466.

82 Ward-Perkins'e göre hem konsollar hem de "rüzgârda sallanan akanthus yaprak biçemi" Suriye kökenlidir. Bkz. Boëthius ve Ward-Perkins, Etruscan, 410. 
Anadolu kökenli mermerin ve Anadolulu bezeme okullarında yaratılan yerel biçemin MS II.-III. yüzyıllarda Akdeniz havzasındaki hemen hemen tüm bölge kentlerinde sevilerek kullanılmasını yalnızca yaşanmaya başlanan refah çağı ve hammadde gereksinimi ile açıklamak doğru olmayacaktır. Köklü bir mimari bezeme geleneğine sahip olan Anadolulu okulların mermere şekil vermedeki maharetleri ve seri üretim kabiliyetleri de tercih edilmelerinde etkili olmuştur. Roma kentinde yapılan çalışmalar sonucunda elde edilen verilere göre Anadolu biçemi başlı başına bir tip olarak değil yerel biçemle harmanlanan karma bir tip olarak karşımıza çıkmaktadır. Yazılı kaynaklar ve yapılan biçem kritiği göstermektedir ki Kuzey Afrika kentlerine yalnızca hammadde ve bezemeli mimari elemanlar ihraç edilmemiş olup, aynı zamanda kaba ya da yarı işlenmiş mermer blokları ile birlikte ustalar da sevk edilmiştir. Suriye-Filistin Bölgesi'nde Anadolu kökenli mermer ihracının yanı sıra yerel mermer ve kireç taşının da kullanıldığ 1 görülür. Özellikle Suriye bölgesinde yerel mermer ve kireçtaşının daha sık kullanıldığı, Filistin bölgesinde ise Marmara mermerinin tercih edildiği bilinmektedir. Bunu yanı sıra yine Anadolulu bezeme okullarından bölgeye giden ustaların ithal ve yerel mermeri işledikleri yazılı kaynakların yanı sıra biçem kritiği yolu ile anlaşılmaktadır. Ancak Suriye bölgesinde Helenistik dönemden beri hâkim olan yerel unsurlar Anadolulu ustalar tarafından çalışılmış, Anadolu kökenli biçem ile harmanlanarak yeni bir biçem haline getirilmiş ve yine aynı ustalarca Anadolu'da yürütülen mimari projelerde kullanılmak suretiyle bir biçem döngüsü yaratılmıştır.

\section{Kaynakça}

Albustanlığlu, Tulga. Roma Imparatorluk Döneminde Mermer Ocakları Organizasyonu. Ankara: Bilgin Kültür Sanat, 2011.

Anabolu, Mükerrem (Usman). İstanbul ve Anadolu'daki Roma Imparatorluk Dönemi Mimarlık Yapıtları. İstanbul: Arkeoloji ve Sanat Yayınları, 2001.

Ball, Warwick. Rome in the East: The Transformation of an Empire. London: Routledge, 2000.

Başaran, Cevat. "Kyzikos Korinth Başlıkları”. Türk Arkeoloji Dergisi 31 (1997): 1-53.

Başaran, Cevat. Anadolu Kompozit Başlıkları. İstanbul: Arkeoloji ve Sanat Yayınları. 1999.

Bejor, Giorgio. Vie Colonnate. Paesaggi Urbani Nel Mondo Antico. Rivista Di Archeologia, Suppllementi 22. Roma: Giorgio Bretschneider, 1999.

Boëthius, Axel, Roger Ling ve Tom Rasmussen. Etruscan and Early Roman Architecture. New Haven: Yale University Press, 1978.

Burns, Ross. Origins of the Colonnaded Streets in the Cities of the Roman East. New York: Oxford University Press, 2017.

Crawford, J. Stephens. The Byzantine Shops at Sardis, Monograph / Archaeological Exploration of Sardis: 9. Cambridge, Mass.: Harvard University Press, 1990.

Dalgıç, Örgü. "Early Christian and Byzantine Churches". Aphrodisias V, The Aphrodisias Regional Survey içinde, derleyen Christopher Ratté ve Peter de Staebler, 367-396. Darmstadt/Mainz: Verlag Philipp von Zabern, 2012.

Fischer, Moshe L. Das Korintische Kapitell im Alten Israel in der Hellenistischen und Römischen Periode: Studien zur Geschichte der Baudekoration im Nahen Osten, Mainz am Rhein: Philipp von Zabern, 1990.

Fischer, Mosche L. Marble Studies: Roman Palestine and the Marble Trade. Konstanz: UVK Universitätsverl, 1998.

Freyberger, Klaus S. "Zur Datierung des Theaters in Bosra". Damaszener Mitteilungen 3 (1988): 17-26, Taf. 9-15. 
Freyberger, Klaus S. "Das Tychaion von as-Şanamain. Ein Vorbericht". Damaszener Mitheilungen 4 (1989): 87-108, Taf. 29-39.

Freyberger, Klaus S. Stadtrömische Kapitelle aus der Zeit von Domitian bis Alexander Severus: zur Arbeitsweise und Organisation Stadtrömischer Werkstätten der Kaiserzeit. Mainz am Rhein: P. von Zabern, 1990.

Heilmeyer, Wolf-Dieter. Korinthische Normalkapitelle. Studien zur Geschichte der Römischen Architekturdekoration. Heidelberg: F. H. Kerle Verlag, 1970.

Hirschland, Nancy L. "The Head-Capitals of Sardis". Papers of the British School at Rome 35 (1967), 12-22.

İdil, Vedat. "Anadolu'da Roma İmparatorluk Çağı Korinth Başlıkları". Anatolia (Anadolu) 20 (1984): 1-49.

Jones, Mark Wilson. Principles of Roman Architecture. 3. Baskı. New Haven: Yale University Press, 2009.

Kaplan, Deniz. "Korykos Antik Kentinin ve Kilikia Bölgesinin Korinth Sütun Başlıkları”. Olba XIV (2006): 89-111.

Koch, Guntram. Roma İmparatorluk Dönemi Lahitleri. Çeviren Z. Zühre İlkgelen. İstanbul: Arkeoloji ve Sanat Yayınları, 2001.

Lendering, Jona. Roma: Mermer Şehir. Çeviren Burak Şengir. İstanbul: Kitap Yayınevi, 2011.

Leon, Christoph F. Die Bauornamentik des Trajansforums und ihre Stellung in der Früh-und Mittelkaiserzeitlichen Architekturdekoration Roms. Böhlau Verlag, 1971.

Mitchell, Stephen ve diğerleri. Cremna in Pisidia: An Ancient City in Peace and in War. London: Duckworth: 1995.

Öğüş, Esen. 2015. “A Late-antique Fountain at Aphrodisias and its Implications for Spoliation Practices". Journal of Roman Archaeology 28 (2015): 302-324.

Pensabene, Patrizio. "Pentelico e Proconnesio in Tripolitania: Coordinamento Concorrenza Nella Distribuzione?". Archeologia Classica 52 (2001): 63-127.

Pensabene, Patrizio. “Marmi d'Importazione, Pietre Locali e Committenza Nella Decorazione Architettonica di età Severiana in Alcuni Centri delle Province Syria et Palestina e Arabia". Archeologia Classica 49 (1997): 275-422.

Peschlow-Bindokat, Anneliese. “Zur Säulenstraße von Pompeiopolis in Kilikien”. Istanbuler Mitteilungen 25 (1975): 373-391, Taf. 71-82.

Richmond, Ian A. "Palmyra Under the Aegis of Rome". The Journal of Roman Studies 53, No 1-2 (1963): 43-54.

Strong, Donald Emrys. "Late Hadrianic Architectural Ornament in Rome". Papers of the British School at Rome 21 (1953): 118-151.

Vandeput, Lutgarde. The Architectural Decoration in Roman Asia Minor. Sagalassos: A Case Study. Leuven: Brepols, 1997.

Ward-Perkins, John Bryan. "Severan Art and Architecture at Lepcis Magna". The Journal of Roman Studies 38, no 1 ve 2 (1948): 59-80.

Ward-Perkins, John Bryan. "Tripolitania and the Marble Trade". The Journal of Roman Studies 41, no 1 ve 2 (1951): 89-104.

Ward-Perkins, John Bryan. "Nicomedia and the Marble Trade". Papers of the British School at Rome 48 (1980): 23-69.

Yıldırım, Şahin. "Soloi-Pompeipolis Liman Caddesi”. Güneş Karadeniz'den Doğar. Sümer Atasoy'a Armağan Yazılar içinde, derleyen Şevket Dönmez, 459-479. Ankara: Hel Yayınları, 2013.

Zanker, Paul. The Power of Images in the Age of Augustus. Ann Arbor: University of Michigan Press, 1990.

\section{Antik Kaynak}

Gaius Suetonius Tranquillus, Divus Augustus. 